\title{
Updated checklist of the rodents of Iraq (Rodentia)
}

\author{
Doplněný soupis hlodavců v Iraku (Rodentia)
}

\section{Montazer Kamel MENSOOR}

International Center for Training, Research and Development (ICTRD), 6135 Executive Blvd, Rockville, MD 20852, United States; montazerkamel@gmail.com

received on 4 November 2020

\begin{abstract}
This paper provides an updated information on the composition and distribution of the rodent fauna of Iraq. The data were taken from field observations that were conducted during the period 2018-2019 in addition to the previous literature and museum collections data. The rodent fauna of Iraq consists of 29 currently recognised species from 17 genera and seven families.
\end{abstract}

Key words. Rodents, Iraq, mammals, distribution.

\section{INTRODUCTION}

Iraq has a diverse mammalian fauna which may be attributed to its zoogeographical regions and different biomes. Iraq has five major biomes (alpine, forests, steppes, marshlands, and deserts) that encompass numerous species of mammals. Rodents are among the largest mammalian orders in Iraq (HATT 1959, HARRISON \& BATES 1991). Rodents represent a very diverse and rich group as they play an active role in maintaining ecosystems. In addition, they harbor many pathogens which makes them very important from a public health perspective (DAHMANA et al. 2020).

There are some previous studies on the rodents of Iraq. However, accurate and detailed information on the zoogeographic distribution of all rodent species occurring in Iraq is not yet available. One of the most important studies on the rodent fauna of Iraq was published by HARRISON (1972) in the third volume of his book Mammals of Arabia. HARRISON (1972) described external characters and general distribution of all rodent species found in Iraq.

HUBBARD (1958) noted that rodent fauna of Iraq could possibly contain 31 species. HATT (1959) included 21 rodent species in his list of mammals occurring in the country. PETTER (1961) found 16 species in the deserts of Iraq. In the checklist of the vertebrates of Iraq elaborated by MAHDI \& GEORGE (1969) there were 27 rodent species. KADIM et al. (1977) counted 24 rodents in Iraq. KADIM (1988) listed 33 species while HARRISON \& BATES (1991) counted 19 species. Al-SHEIKHLY et al. (2015) included 28 species in their checklist of mammals of Iraq.

It is important to regularly update the list of the living rodent species occurring in Iraq since most of these rodents are of medical importance as they are capable of transmitting dangerous diseases to humans. In addition, rodents can be good indicators of local biodiversity as a result of their specialization to specific types of ecosystems and their low distribution ability (BRYJA et al. 2019). 


\section{MATERIAL AND METHODS}

All new records of rodent species were identified from photos obtained using camera traps and/or direct observations in the field. All rodent species recently recorded were captured by hand and identified in accordance to WILSON et al. (2017). The zoological collections of the following museums were reviewed: Iraqi Natural History Research Centre and Museum, Baghdad, Iraq (BRCB); National Museum of Natural History, Paris, France (MNHN); Field Museum of Natural History, Chicago, United States of America (FMNH); Zoologisches Forschungsmuseum Alexander Koenig (ZFMK). This checklist is organized according to the systematic order.

\section{LIST OF SPECIES}

\section{Sciuridae}

\section{Caucasian (Persian) squirrel, Sciurus anomalus (Gmelin, 1778)}

Published records. (1) Tinn near Bamerne, (2) Ser Amadia (Harrison 1956a); (3) Penjwin (Baltazard \& Seydian 1960, Petter 1961); (4) Koshek (von Lehmann 1966); (5) Derbendikhan Dam (Harrison \& Bates 1991); (6) Hawraman Mountain (Lahony et al. 2013); (7) Safeen Mountain (Al-Zubaidi et al. 2014). Museum ReCords. (3) Penjwin (MNHN); (8) Baradost Mountain, 1954 (FMNH); (9) Kirkuk, 1955 (FMNH); (5) Darbandikhan, 1957 (ZFMK).

New records. (10) Sersink, (11) Ranya.

A very common species in the northeasternmost mountain forests of Iraq (Fig. 1).
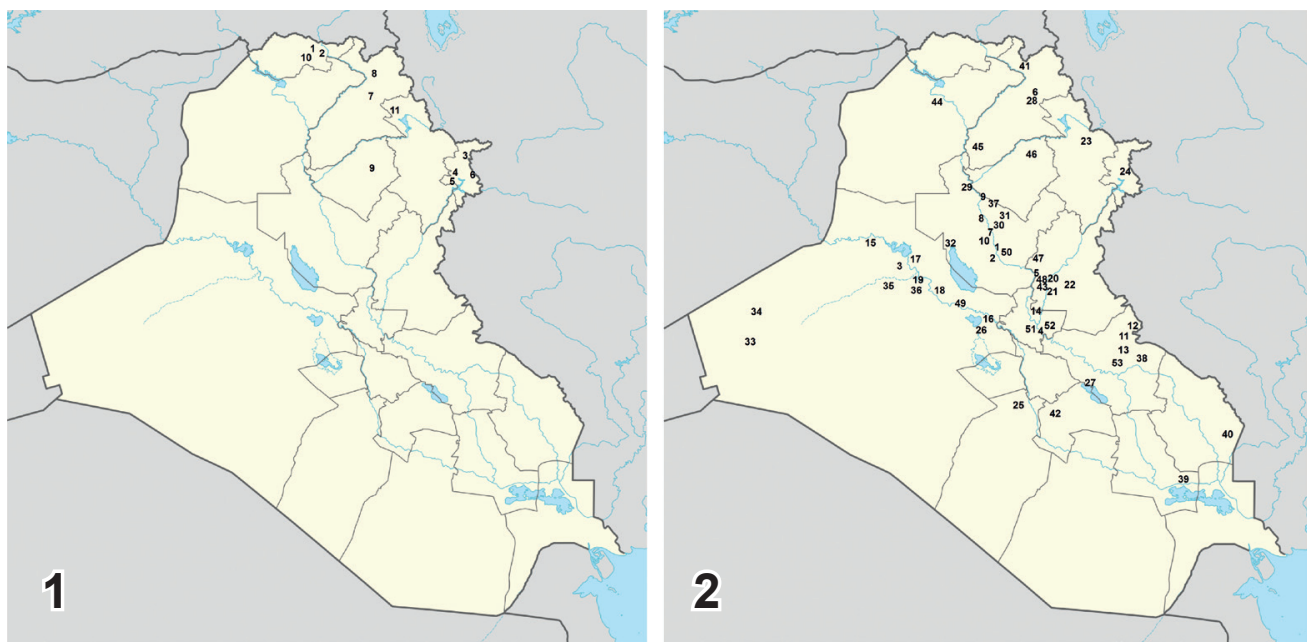

Figs. 1, 2. Distribution of particular rodent species in Iraq. The numbers in the maps correspond with the site numbers in the lists of records. 1 - Caucasian suirrel (Sciurus anomalus). 2 -Indian crested porcupine (Hystrix indica).

Obr. 1, 2. Rozšíření jednotlivých druhů hlodavců v Iraku. Čísla v mapách odpovídají číslům lokalit v soupisech nálezů. 1 - veverka perská (Sciurus anomalus). 2 - dikobraz indický (Hystrix indica). 
Hystricida e

\section{Indian crested porcupine, Hystrix indica (Kerr, 1792)}

Published records. (1) between Samarra and Tikrit (Chessman 1920); (2) Samarra (Ellerman 1948); (3) Wadi Haqlan, (4) Ctesiphon, (5) Mansuriyat Al-Shatt (Hatт 1959); (6) $20 \mathrm{~km}$ north of Shaqlawa (NADACHOWski et al. 1990); (7) Tikrit, (8) Baiji, (9) Al-Fatha, Samara, (10) Dour, (11) Badra, (12) Zurbatia, (13) South Jassan, (14) north-east Baghdad, (15) South Rawa, (16) near Faluja, (17) North Haditha, (18) North Hit, (19) Al-Baghdadi, (20) Baquba, (21) South Baquba, and (22) Baladrouze (KadHIM 1997); (23) Jazhna Mountain (RAZA et al. 2012); (24) Hawraman Mountain (LAHONY et al. 2013); (25) Bahr Al-Najaf (Mohammad et al. 2013); (26) areas around Razzaza Lake (Mohammad \& Ali 2013, Mohammad \& AlZubaidi 2017); (27) Dalmaj Marsh (Mohammad 2014); (28) Safeen Mountain (Al-Zubaidi et al. 2014); (29) Jabal Makhool, (30) Al-Alam, (31) Al-Cidir, (32) Al-Tharthar Valley, (33) Rutba, (34) Ga'ara, (35) Wadi Horan, (36) Khan Al-Baghdadi, (37) Jabal Himreen, (38) near Shwecha Marsh, Dalmaj Marsh, (39) Central Marshes (Al-SheIKHLY et al. 2015); (40) Huwaiza Marshes (Al-Zubaidi et al. 2017); (41) Shanidar and Hawraman caves (Moнамmad et al. 2017); (42) Diwaniya (КАднiм 2017, 2018).

Museum records. (43) Baquba, 1946 (BRCB).

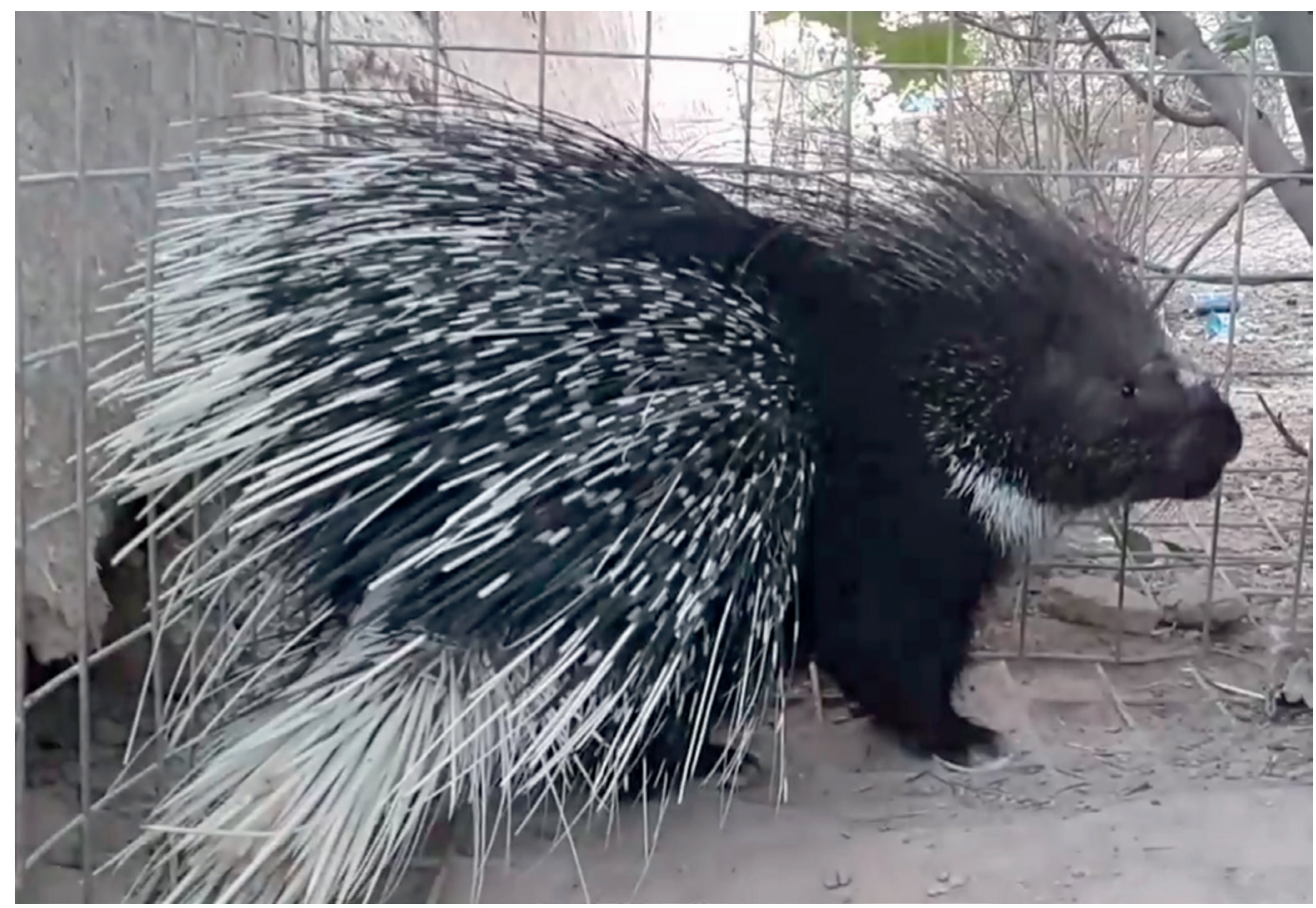

Fig. 3. An Indian crested orcupine (Hystrix indica) captured at Al-Udaim in the Diyala Province, Iraq. Obr. 3. Dikobraz indický (Hystrix indica) odchycený v Al Udaimu v provincii Dijala ve východním Iraku. 
New records. (44) Badush; (45) Makhmoor, Makhool mountains; (46) Baba Gurgur; (47) Al-Udhaim (Fig. 3); (48) Al-Huayder; (49) Ramadi; (50) Samarra; (51) Bu'aitha; (52) Al-Adwaniya; (53) Kut, Badra, Al-Tharthar, Dalmaj Marsh.

Widespread in the areas around the Tigris and Euphrates rivers (Fig. 2).

D i p o d id a e

\section{Euphrates jerboa, Allactaga euphratica (Thomas, 1881)}

Published records. (1) Baquba, (2) near Diyala River, (3) Baghdad (ElLerman 1948); Baqubah, Bahdad, (4) Ramadi (Harrison 1972); (5) Mosul (Al-RobaAe 1976); (6) Samara, (7) Dholuiya, (8) Dour, (9) Tikrit, (10) Baiji, (11) Hatra (KadHIM et al. 1979); Baghdad, (12) Basrah, (13) Najaf (JAwDAT \& Al-JAFARY 1980); Samara (KadHim et al. 1986); Hatrah (NADACHowsKi et al. 1990); Baghdad, (14) Kerbala (Mohammed 1999); (15) south of Basrah in the Demilitarized zone between Iraq and Kuwait (AlsDIRAWI \& FARAJ 2004); (16) west of Hammar Marsh (AL-SHeikHLY et al. 2015); (17) areas around Razzaza Lake (MohAmmAD \& Al- Zubaidi 2017); (18) Huwaiza Marshes (Al-Zubaidi et al. 2017); (19) Samawa (Anonymous 2018).

Museum records. (20) Abu Ghraib (BRCB).

New records. (21) Amarah; (22) Nasiriya; (23) Delmaj Marsh.

Common along the Tigris and Euphrates river banks in Iraq (Fig. 4).
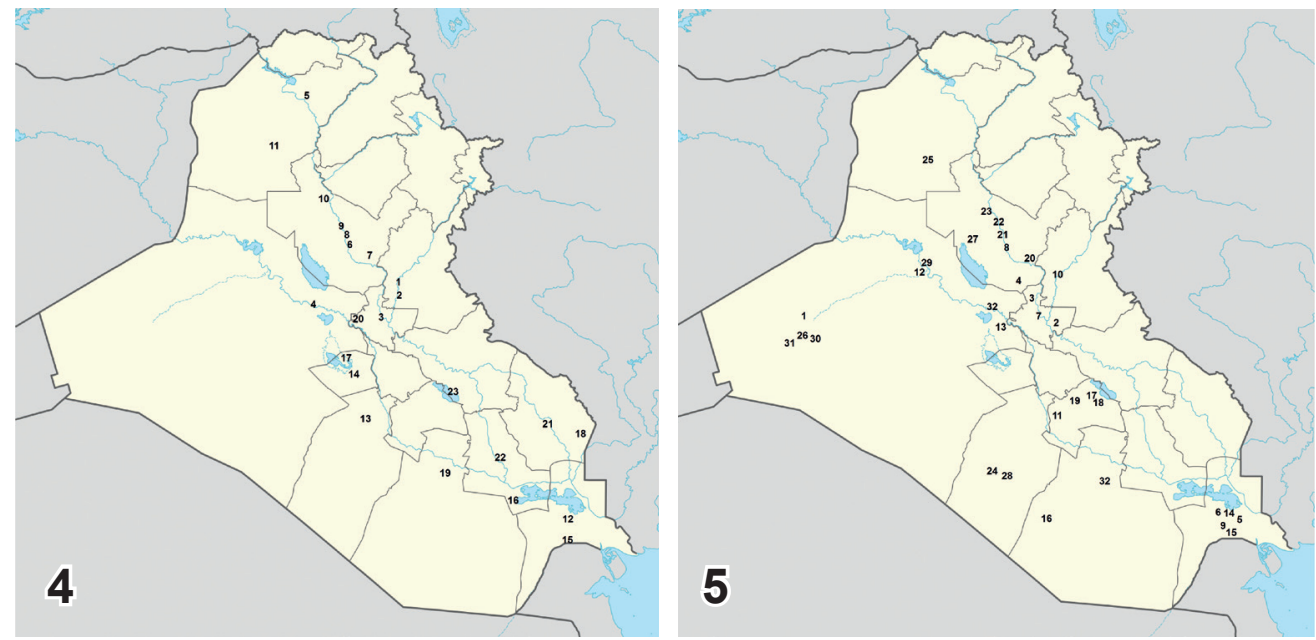

Figs. 4, 5. Distribution of particular rodent species in Iraq. The numbers in the maps correspond with the site numbers in the lists of records. 4 - Euphrates jerboa (Allactaga euphratica). 5 -Egyptian jerboa (Jaculus jaculus).

Obr. 4, 5. Rozšíření jednotlivých druhů hlodavců v Iraku. Č́sla v mapě odpovídají číslům lokalit v soupisech nálezů. 4 - frček dlouhouchý (Allactaga euphratica). 5 - tarbík egyptský (Jaculus jaculus). 

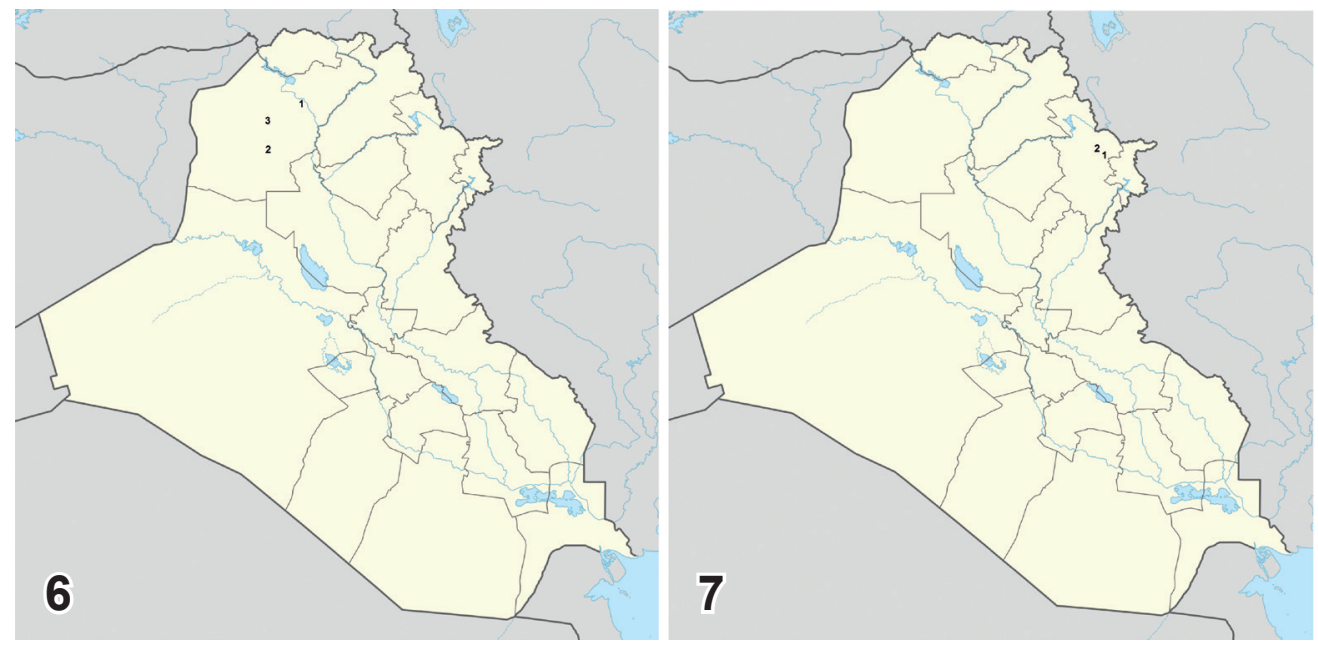

Figs. 6, 7. Distribution of particular rodent species in Iraq. The numbers in the maps correspond with the site numbers in the lists of records. 6 - large-eared garden dormouse (Eliomys melanurus). 7 - forest dormouse (Dryomys nitedula).

Obr. 6, 7. Rozšíření jednotlivých druhů hlodavců v Iraku. Čísla v mapě odpovídají číslům lokalit v soupisech nálezů. 6 - plch černoocasý (Eliomys melanurus). 7 - plch lesní (Dryomys nitedula).

\section{Lesser Egyptian jerboa, Jaculus jaculus (Linnaeus, 1758)}

Published records. (1) H3 station (SANBORN 1940); (2) Rustumiya, (3) Kadhumiyah, (4) Aqar Quf, (5) Zubair (Ellerman 1948); (6) Basrah, (7) Baghdad (Hubbard 1956, 1960); (8) Samara (Harrison 1958); (9) $59 \mathrm{~km}$ west of Basrah, (10) Baquba, (11) Shamiya Desert, (12) south of Haditha (Hatт 1959); (13) Haur Al-Hasa, (14) Al-Zubair (HARrison 1972); Al-Zubair, (15) Safwan, (16) Al-Salman, (17) Afaq, (18) Badir, (19) Niffar, Samarra, (20) Dholuiya, (21) Dour, (22) Tikrit, (23) Baiji, (24) Najaf desert, (25) Hatra (KadHim et al. 1979); (26) Rutba (Shamsuddin \& Mohammad 1988); Hatrah, 40 km east of Rutba (NADACHOwski et al. 1990); (27) Wadi Al-Tharthar (Al-Sheikhly et al. 2015); (28) Najaf Desert (Al-Jebori 2016). Museum records. (29) Haditha, 1967 (MNHN); (30) Rutba, 1934 (FMNH); (31) Rutba, 1965 (ZFMK). New records. (32) Fallujah, (33) Samawa.

Common in lowland deserts of Iraq (Fig. 5).

G 1 ir i d a e

\section{Large-eared garden dormouse, Eliomys melanurus (Wagner, 1840)}

Published records. (1) Mosul (Pietschmann 1912); (2) Hatra (Nadachowski et al. 1978, 1990); (3) 90 km southwest of Mosul (HARrison \& Bates 1991).

A rare species restricted to the dry steppes of northwestern Iraq (Fig. 6). 


\section{Forest dormouse, Dryomys nitedula (Pallas, 1779)}

Published records. (1) Sulaymaniyah (Jawdat 1977, Harrison \& Bates 1991).

New records. (2) Sulaymaniyah.

Restricted to the forests of northeastern Iraq (Fig. 7).

S p a l a c i d a e

\section{Middle eastern blind mole rat, Nannospalax ehrenbergi (Nehring, 1898)}

Published records. (1) Hazar Mard Caves (BATE 1930); (2) Ser Amadia, (3) Tinn (Harrison 1956a); (4) Jarmo, (5) Chemchamal Valley (Reed 1958); (6) Sersink (Hubbard 1955, Hatt 1959); (7) Penjwin (Petter 1961); Jarmo, (8) Palegawra Cave (Turnbull \& ReEd 1974); (9) 22 km southwest of Mosul, (10) Al-Jurn (CoșKun et al. 2012, 2016); Al-Jurn, (11) Shwan, (12) Mughagh (CoșKun et al. 2014); Shwan, Mughagh, (13) Bardarash, (14) Erbil (HAmAd et al. 2019).

New records. (15) Sulaymaniyah.

A species restricted to the mountainous northwestern part of Iraq (Fig. 8).
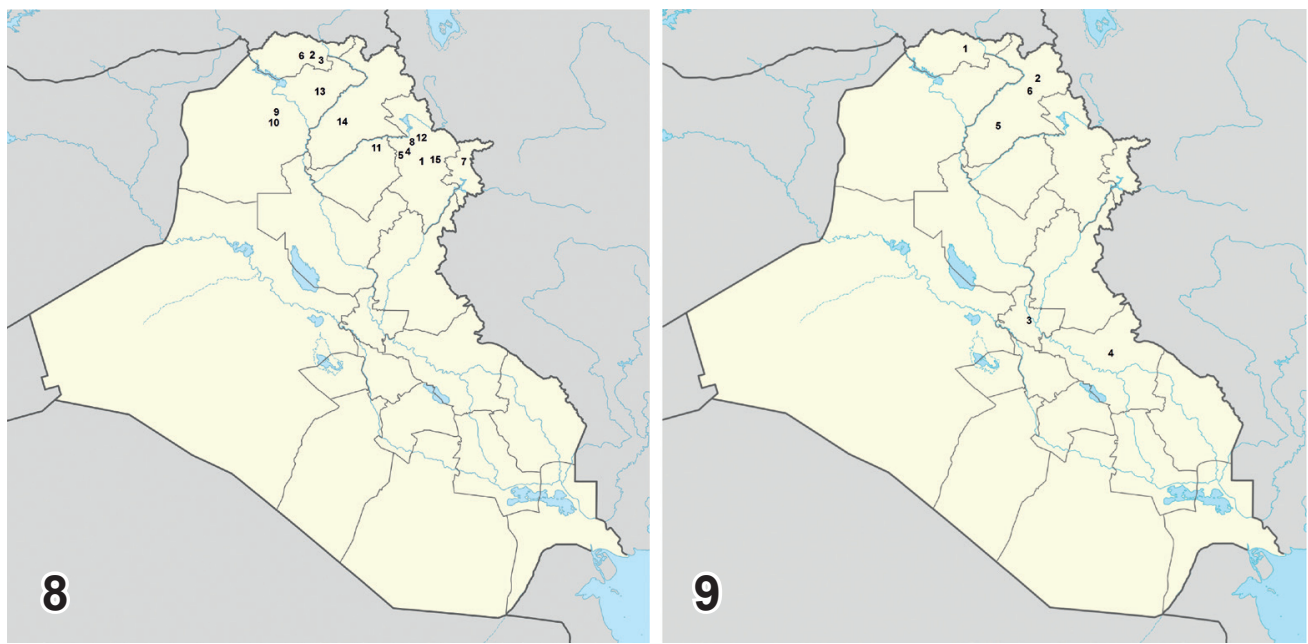

Figs. 8, 9. Distribution of particular rodent species in Iraq. The numbers in the maps correspond with the site numbers in the lists of records. 8 - Middle Eastern blind mole rat (Nannospalax ehrenbergi). 9 - eastern broad-toothed field mouse (Apodemus mystacinus).

Obr. 8, 9. Rozšíření jednotlivých druhů hlodavců v Iraku. Čísla v mapě odpovídají číslům lokalit v soupisech nálezů. 8 - slepec egyptský (Nannospalax ehrenbergi). 9 - myšice krasová (Apodemus mystacinus). 

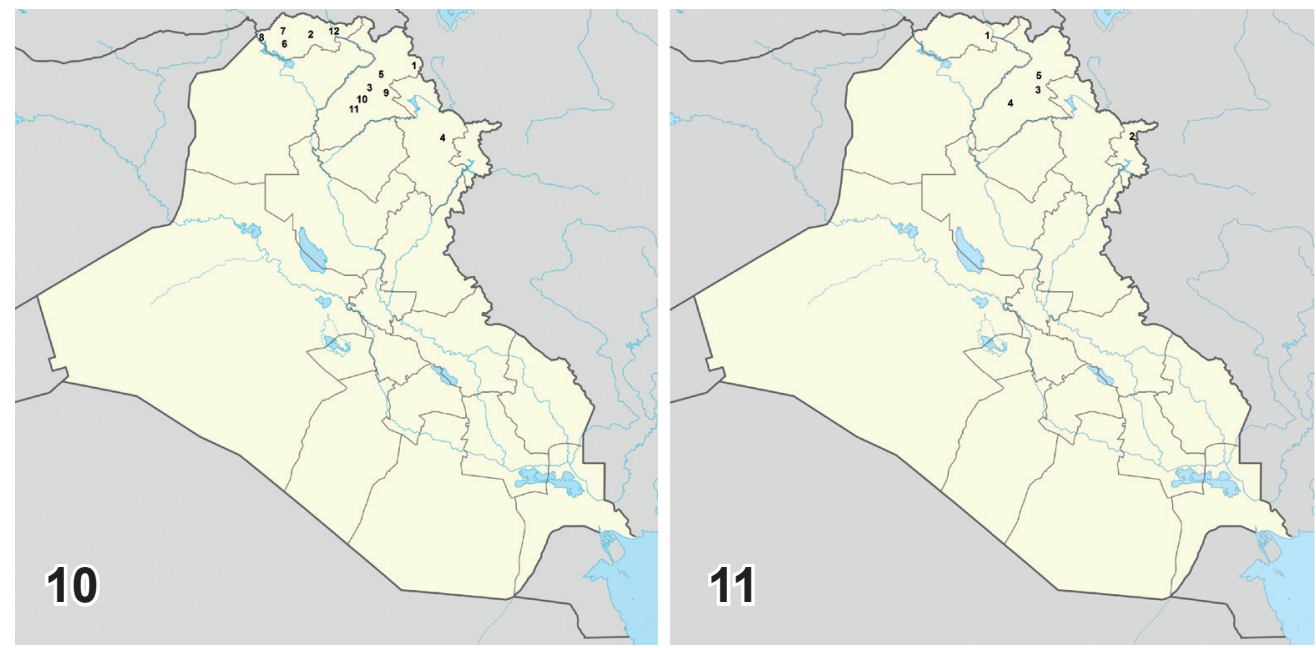

Figs. 10, 11. Distribution of particular rodent species in Iraq. The numbers in the maps correspond with the site numbers in the lists of records. 10 - yellow-necked field mouse (Apodemus flavicollis). 11 - longtailed field mouse (Apodemus sylvaticus)

Obr. 10, 11. Rozšiřrení jednotlivých druhů hlodavců v Iraku. Čísla v mapě odpovídají číslům lokalit v soupisech nálezů. 10 - myšice lesní (Apodemus flavicollis). 11 - myšice křovinná (Apodemus sylvaticus).

Muridae

Eastern broad-toothed field mouse, Apodemus mystacinus (Danford et Alston, 1877)

Published records. (1) Sersink (Hubbard 1955, Hatt 1959); (2) Geli Ali Beg (Nadachowski et al. 1990); (3) Baghdad, (4) Kut (Mohammad 2008).

Museum records. (5) Erbil, 1954 (FMNH).

New records. (6) Shaqlawa.

A rarely documented species, known from the northern and eastern parts of Iraq (Fig. 9).

\section{Yellow-necked field mouse, Apodemus flavicollis (Melchior, 1834)}

Pulished records. (1) Haj Omran, (2) Sersink (Hatт 1959); (3) Salahadin, (4) Sulaymaniyah (Al-ShEnawi et al. 1982, Harrison \& Bates 1991); (5) Shaqlawa (NAdachowski et al. 1990); (6) Sumel, (7) Girshin, (8) Faysh Khabur, (9) Erbil, (10) Shawees (Khedher 2014, Khedher \& Khalaf 2019).

New records. (11) Erbil, (12) Amadiya.

A species occurring in the northern mountainous part of Iraq (Fig. 10).

\section{Long-tailed field mouse, Apodemus sylvaticus (Linnaeus, 1758)}

Published records. (1) Ser Amadia (Harrison 1956a); (2) Penjwin (Petter 1961); (3) Safeen Mountain (Al-Zubaidi et al. 2014). 
Museum records. (2) Penjwin (MNHN).

New records. (4) Erbil, (5) Shaqlawa.

A rare species, distributed only in the northeastern part of the country (Fig. 11).

\section{Steppe field mouse, Apodemus witherbyi (Thomas, 1902)}

Published records. (1) Ser Amadiya (Harrison 1956a, Hatt 1959).

New records. (2) Sersink.

A rare species, documented only in the north of Iraq (Fig. 12).

\section{Roof rat, Rattus rattus (Linnaeus, 1758)}

Published records. (1) Erbil (Molan \& Hussein 1988); (2) Baghdad, (3) Kut (MoHAmmad 2008); (4) Al-Rasheed (Salman 2009); (5) Bahr Al-Najaf (Mohammad et al. 2013); Kut, Baghdad, (6) Hillah, (7) Kerbala, (8) Najaf, (9) Samawa, (10) Amarah, (11) Nasiriya, (12) Basrah (ShubBer et al. 2014); (13) Dalmaj Marsh (Mohammad 2014); (14) Old Rasafa, (15) Yarmook (Al-Sheikhly et al. 2015); (16) Adhamiya, (17) Kadhimiya, (18) Ameriya (MaJeEd 2016); Al-Rasheed, (19) Aqar Quf (Al-ObaIDI et al. 2017); Baghdad, (20) Ramadi, (21) Fallujah, (22) Hit (Shahatha \& Saleh 2018); (23) Kifri, (24) Kalar, (25) Khanaqin (AmIN 2019).

Museum records. (26) Balad (MNHN); (27) Mosul, 1934 (FMNH).

New records. (28) Al-Ghizlani, (29) Tal Afar, (30) Tikrit, (31) Samarra, (32) Baquba.
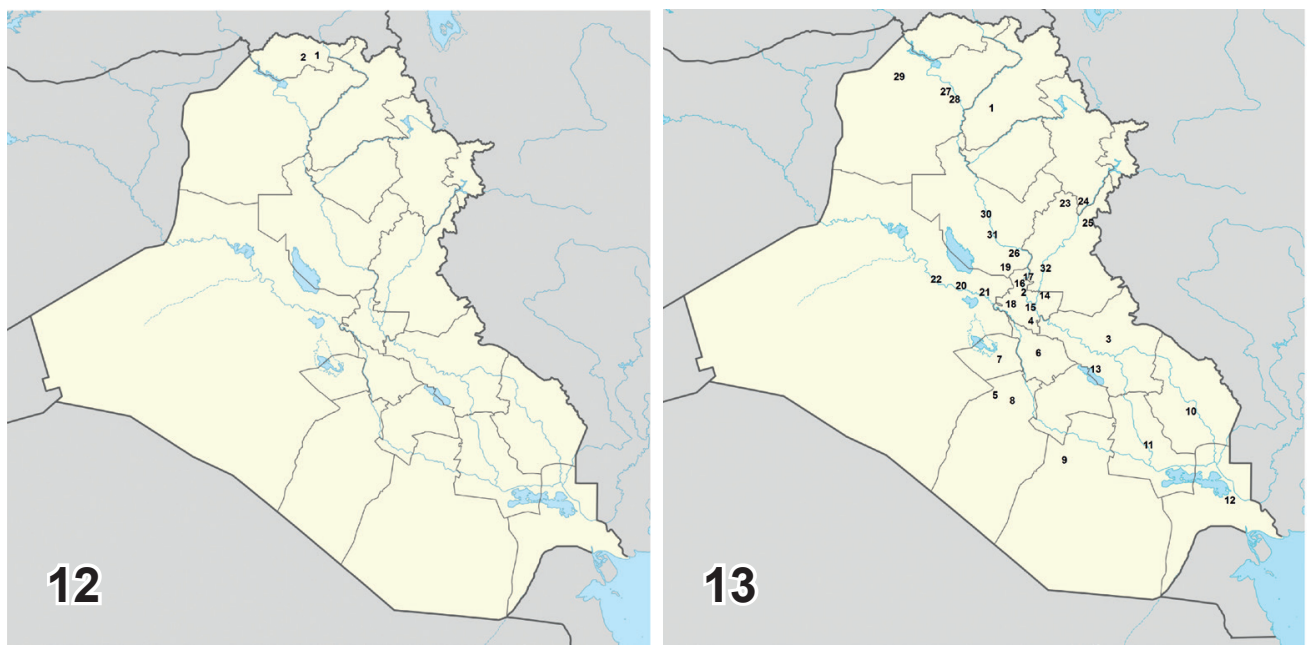

Figs. 12, 13. Distribution of particular rodent species in Iraq. The numbers in the maps correspond with the site numbers in the lists of records. 12 - steppe field mouse (Apodemus witherbyi). 13 - roof rat (Rattus rattus).

Obr. 12, 13. Rozšiření jednotlivých druhů hlodavců v Iraku. Čísla v mapě odpovídají číslům lokalit v soupisech nálezů. 12 - myšice stepní (Apodemus witherbyi). 13 - krysa obecná (Rattus rattus). 

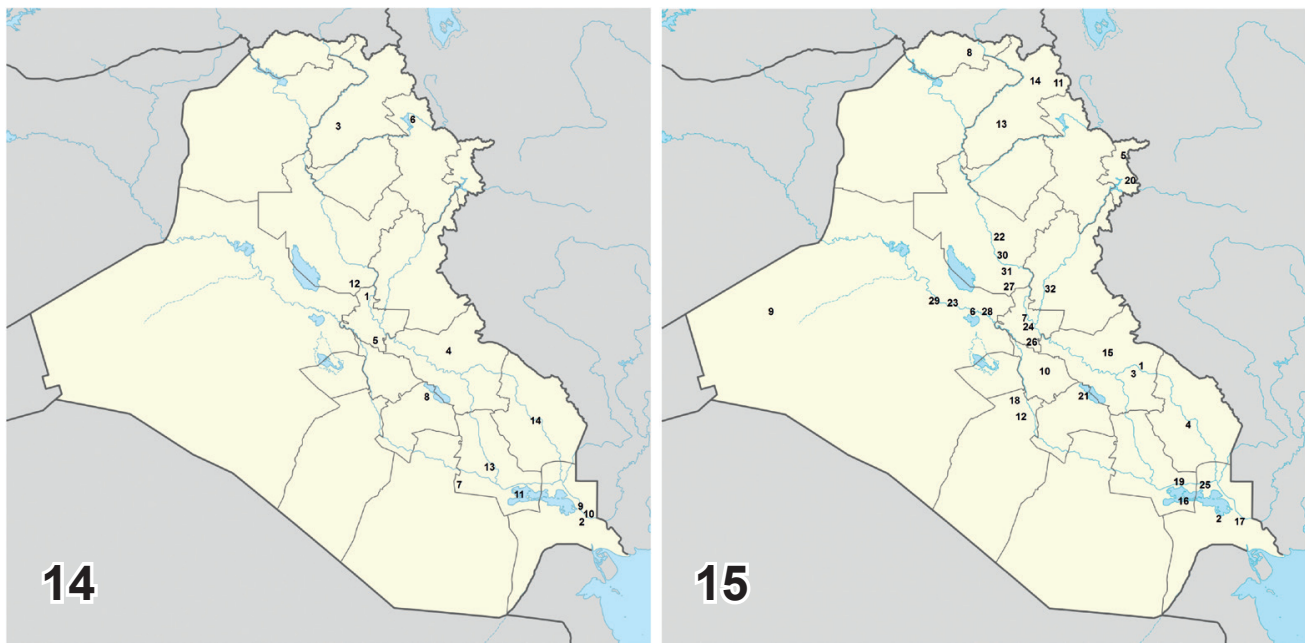

Figs. 14, 15. Distribution of particular rodent species in Iraq. The numbers in the maps correspond with the site numbers in the lists of records. 14 - brown rat (Rattus norvegicus). 15 - house mouse (Mus musculus). Obr. 14, 15. Rozšíření jednotlivých druhů hlodavců v Iraku. Čísla v mapě odpovídají číslům lokalit v soupisech nálezů. 14 - potkan norvéžský (Rattus norvegicus). 16 - myš domácí (Mus musculus).

A very widespread synanthropic rodent, occurring throughout the country (Fig. 13).

\section{Brown rat, Rattus norvegicus (Berkenhout, 1769)}

Published records. (1) Baghdad (Jordan 1938); (2) Basra (CheEsman 1920, Hatt 1959); Baghdad (KadHim et al. 1979, Al-Shenawi et al. 1982, Harrison \& Bates 1991); (3) Erbil (Molan \& Hussein 1988); Baghdad, (4) Kut (Mohammad 2008); (5) Al-Rasheed (Salman 2009); (6) Dukan Lake (Haba 2013); (7) Hammar Marsh (Abbas 2013); (8) Dalmaj Marsh (Mohammad 2014); Baghdad, (9) Al-Mashab, (10) Garmatt Ali (Al-SheIKHLy et al. 2015); (11) East Hammar Marsh (Abbas \& Hussain 2015); Al-Rasheed, (12) Aqar Quf (Al-Obaidi et al. 2017); Basrah, (13) Nasiriya, (14) Amarah (Hatem et al. 2018).

A medium common urban pest that is associated with humans, documented mainly from southern and eastern Iraq (Fig. 14).

\section{House mouse, Mus musculus (Linnaeus, 1758)}

Published records. (1) Sinn Abtar, (2) Basra, (3) Shaikh Saad, (4) Amara (Cheesman 1920); (5) Penjwin (Petter et al. 1957); (6) Habbaniyah, (7) Baghdad, (8) Sersink, (9) K-3, (10) Hilla, (11) Haj Omran (Hatt 1959); (12) Najaf (Nader 1968); (13) Erbil (Molan \& Hussein 1988); (14) Geli Ali Beg (Nadachowski et al. 1990); Baghdad, (15) Kut (Mohammad 2008); (16) Chebayyesh, (17) Ashar (Haba 2009); (18) Bahr Al-Najaf (Mohammad et al. 2013); (19) Hammar Marsh (AbBas 2013); (20) Hawraman Mountain (Lahony et al. 2013); (21) Dalmaj Marsh (Mohammad 2014); (22) Al-Alam, (23) Ramadi, (24) Yarmook 
area (Al-Sheikhly et al. 2015); (25) East Hammar Marsh (AbBas \& Hussain 2015); (26) Al-Rasheed, (27) Aqar Quf (Al-Obaidi et al. 2017); Baghdad, Ramadi, (28) Fallujah, (29) Hit (Shahatha \& Saleh 2018). Museum records. (13) Erbil, 1954 (FMNH).

New records. Falluja, (30) Samarra, (31) Dijail, (32) Baquba.

A very common urban pest that is associated with humans (Fig. 15)

\section{Short-tailed nesokia, Nesokia indica (Gray, 1830)}

Published records. (1) Amara, (2) A1-Qurna, (3) Aqar Quf, (4) Shaikh Saad, (5) Nasiriya (Cheesman 1920); (6) Baghdad (Sanborn 1940); (7) Maqil, (8) Hinaidi (Ellerman 1948); (9) Ur (Pocock 1934); Baghdad, (10) Mansuriyat Al-Shatt, (11) Ramadi, (12) Babylon (Hatt 1959); (13) Ali Al-Gharbi (BAltaZARD \& SEYdian 1960, Petter 1961), (14) Najaf (Nader 1968); (15) Al-Jaderiya (Nader 1969); (16) Basrah (Al-RobaAe 1977); Baghdad, Basrah, Najaf (JAWDat \& Al-JafarY 1980); (17) Abu Ghraib (KaDHIM 1998); Aqar Quf, (18) Hatrah (NAdAchowski et al. 1990); (19) Al-Rasheed (SAlman 2009); (20) Bahr Al-Najaf (Mohammad et al. 2013); (21) areas around Razzaza Lake (Mohammad \& Ali 2013, Mohammad \& Al-Zubaidi 2017); (22) Hammar Marsh (ABbas 2013, AbBas \& Hussain 2015); Al-Rasheed, Aqar Quf (Al-Obaidi et al. 2017); (23) Huwaiza Marsh (Al-Zubaid et al. 2017); (24) Samawa (Anonymous 2018).

Museum records. (25) Habbaniya (MNHN); Baghdad, 1935 (FMNH).

New records. (26) Fallujah, (27) Delmaj Marsh, (28) Al-Hammar Marsh.

A species distributed mainly in lowland areas of Iraq (Fig. 16).
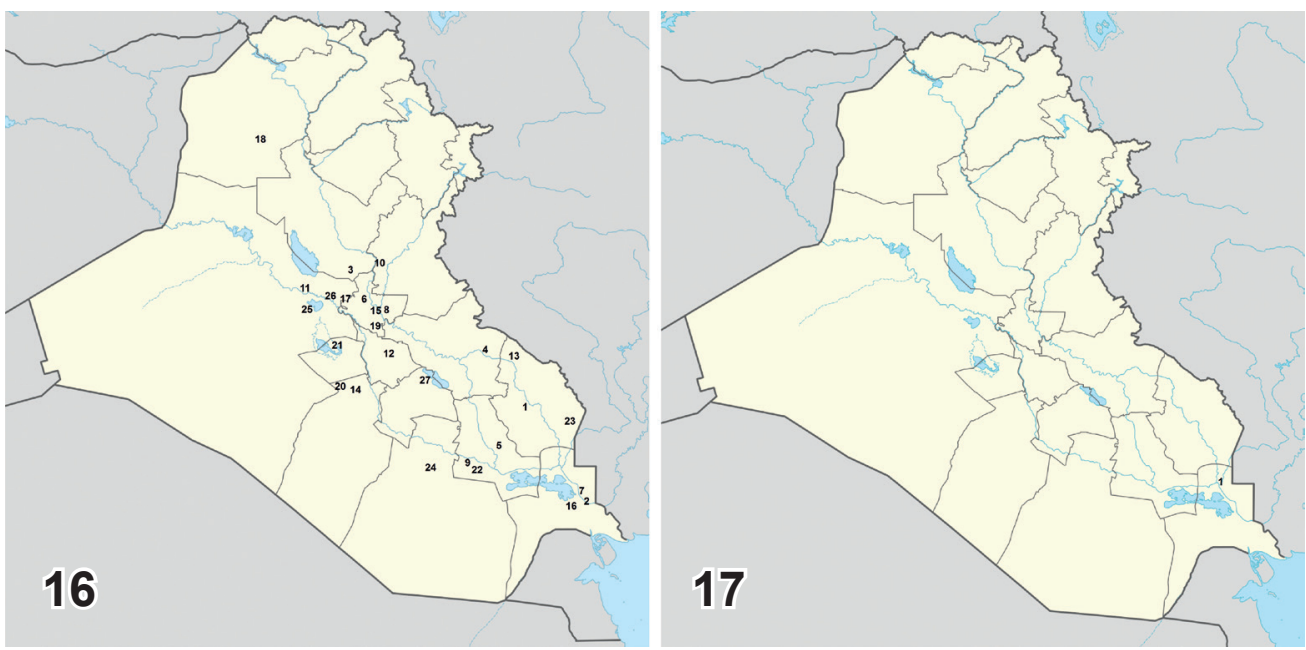

Figs. 16, 17. Distribution of particular rodent species in Iraq. The numbers in the maps correspond with the site numbers in the lists of records. 16 - short-tailed nesokia (Nesokia indica). 17-long-tailed nesokia (Nesokia bunnii).

Obr. 16, 17. Rozšiření jednotlivých druhů hlodavců v Iraku. Čísla v mapě odpovídají číslům lokalit v soupisech nálezů. 16 - krysa morová (Nesokia indica). 17 - krysa Bunnova (Nesokia bunnii). 

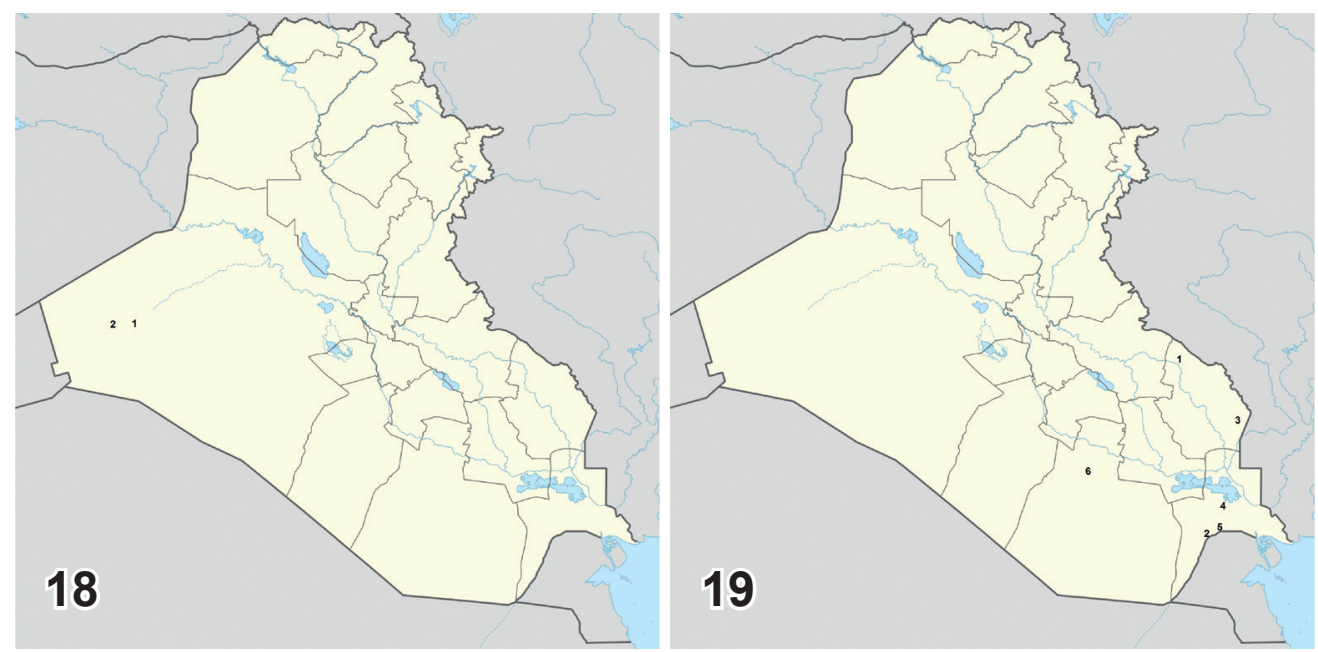

Figs. 18, 19. Distribution of particular rodent species in Iraq. The numbers in the maps correspond with the site numbers in the lists of records. 18 - pygmy gerbil (Gerbillus henleyi). 19 - Baluchistan gerbil (Gerbillus nanus).

Obr. 18, 19. Rozšíření jednotlivých druhů hlodavců v Iraku. Čísla v mapě odpovídají číslům lokalit v soupisech nálezů. 18 - pískomil Henleyův (Gerbillus henleyi). 19 - pískomil menší (Gerbillus nanus).

\section{Long-tailed nesokia, Nesokia bunnii (Khajuria, 1981)}

Published records. (1) Al-Qurna (Khajuria 1981, Evans 1994, Al-RobaAe \& Felten 1990, Kryštufek et al. 2017).

A rare species, confined to the marshes of southeastern Iraq (Fig. 17).

\section{Pygmy gerbil, Gerbillus henleyi (de Winton, 1903)}

Published records. (1) Rutba (Abdul-Rassoul \& Mohammad 1988, Монammed 1999).

New records. (2) $30 \mathrm{~km}$ west of Rutba.

A very rare species restricted to the deserts of western Iraq (Fig. 18).

\section{Baluchistan gerbil, Gerbillus nanus (Blanford, 1875)}

Published records. (1) Ali Al-Gharbi (Petter et al. 1957, Baltazard \& Seydian 1960, Petter 1961); (2) south of Basrah in the Demilitarized zone between Iraq and Kuwait (AlsdiraWI \& Faraj 2004); (3) Huwaiza Marshes (Al-Zubaidi et al. 2017); (4) Basra (Harrison \& Bates 1991).

New records. (5) Safwan, (6) Samawa.

An uncommon species occurring in dry deserts of southeastern Iraq (Fig. 19). 


\section{Wagner's gerbil, Gerbillus dasyurus (Wagner, 1842)}

Published records. (1) Baghdad, (2) Amarah (Cheesman 1920, Geptner 1940); (3) 11 km SE H2 pumping station in western Iraq (Harrison 1956a); Baghdad (Hubbard 1956); (4) Haditha (Hatt 1959, Harrison \& Bates 1991); (5) Ali Al-Gharbi (Petter et al. 1957, Baltazard \& Seydian 1960, Petter 1961); (6) near Baghdad (LewIs 1974); (7) south of Basrah in the Demilitarized zone between Iraq and Kuwait (AlsDIRAwI \& FARAJ 2004); (8) Wadi Al-Tharthar (Al-SheIKHLY et al. 2015).

New records. (9) Safwan.

An uncommon species found in the desert lowlands of the Euphrates and Tigris rivers (Fig. 20).

\section{Mesopotamian gerbil, Gerbillus mesopotamiae (Harrison, 1956)}

Published records. (1) Ali Al-Gharbi (Petter 1961); (2) Al-Jaderiya (NAder 1969); (3) Central Marshes (Evans 1994).

A rare species known from three sites in the Tigris river valley (Fig. 21).

\section{Cheesman's gerbil, Gerbillus cheesmani (Thomas, 1919)}

Published records. (1) between Basrah and Nasiriya (Cheesman 1920); (2) Hawr Al-Hasa, (3) Amiriya, along the west bank of the Euphrates, (4) south west of Faluja (HARRISON 1956b); (5) Habbaniya Lake (Petter et al. 1957, Hatt 1959).
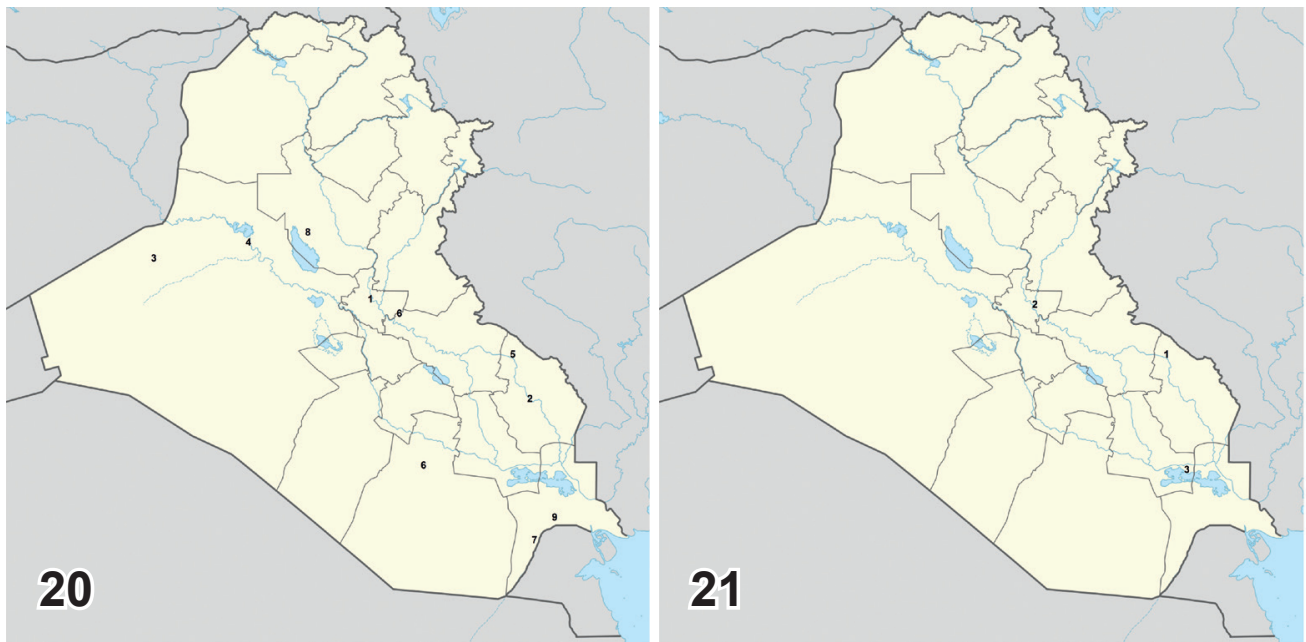

Figs. 20, 21. Distribution of particular rodent species in Iraq. The numbers in the maps correspond with the site numbers in the lists of records. 20 - Wagner's gerbil (Gerbillus dasyurus). 21 - Mesopotamian gerbil (Gerbillus mesopotamiae).

Obr. 20, 21. Rozšíření jednotlivých druhů hlodavců v Iraku. Čísla v mapě odpovídají číslům lokalit v soupisech nálezů. 20 - pískomil štětkatý (Gerbillus dasyurus). 21 - pískomil mesopotamský (Gerbillus mesopotamiae). 

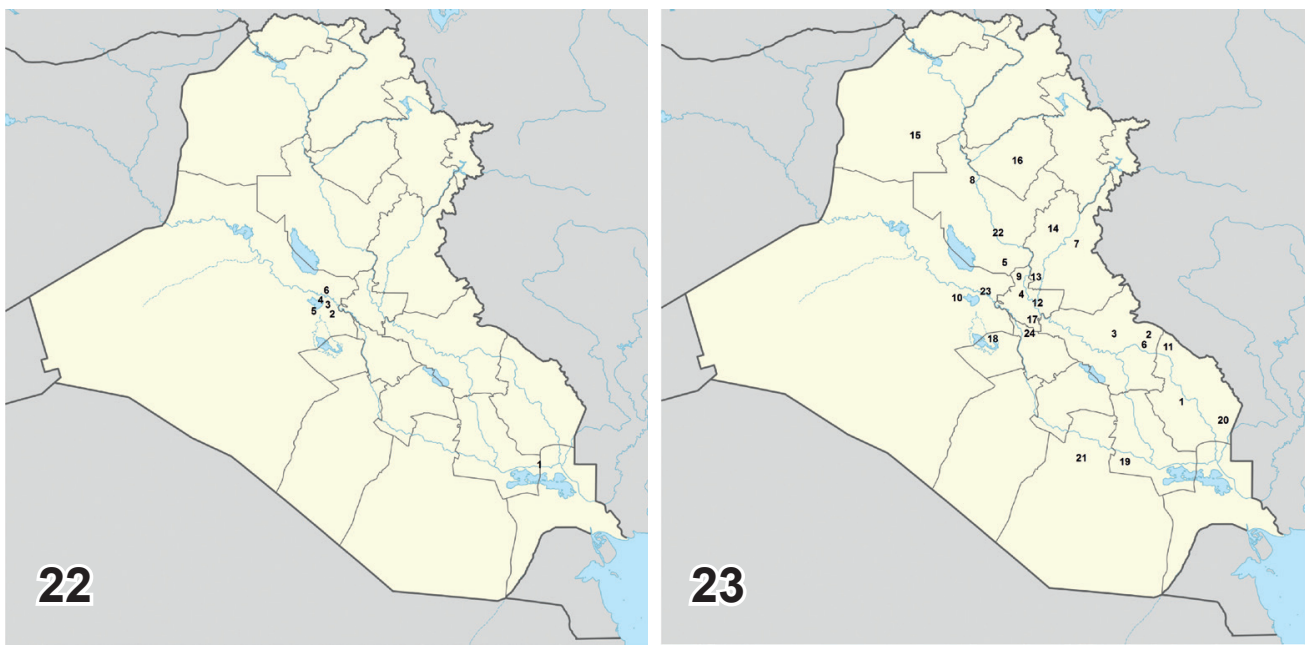

Figs. 22, 23. Distribution of particular rodent species in Iraq. The numbers in the maps correspond with the site numbers in the lists of records. 22 - Cheesman's gerbil (Gerbillus cheesmani). 23 - Indian gerbil (Tatera indica).

Obr. 22, 23. Rozšiření jednotlivých druhů hlodavců v Iraku. Čísla v mapě odpovídají číslům lokalit v soupisech nálezů. 22 - pískomil Cheesmanův (Gerbillus cheesmani). 23 - pískomil indický (Tatera indica).

New records. (6) Falluja.

A rare species occurring in a limited area of central Iraq (Fig. 22).

\section{Indian gerbil, Tatera indica (Hardwicke, 1807)}

Published records. (1) Amara, (2) Sinn Abtar, (3) Kut, (4) Baghdad, (5) Aqar Quf, (6) Sheikh Saad, (7) Shahraban, (8) Baiji (Cheesman 1920); (9) Kadumiya, Baghdad (Ellerman 1948); (10) near Habbniya (Harrison 1956b); (11) Ali Al-Gharbi (Petter et al. 1957, Baltazard \& Seydian 1960, Petter 1961); (12) Jaderiya (NADER 1969); Jaderiya, (13) Rashdiya (Mirza \& AL-RawaS 1975); (14) Tell Imlihiye (Kock \& Nader 1983); (15) Hatra (NAdAchowski et al. 1978, 1990, Harrison \& Bates 1991); Aqar Quf, Baghdad (NADACHOwsKi et al. 1990); Kut, Diyala, (16) Kirkuk (KaDHIM 1998); (17) Al-Rasheed (SAlmaN 2009); (18) areas around Razzaza Lake (Mohammad \& Ali 2013, Mohammad \& Al-Zubaidi 2017); (19) Hammar Marsh (AbBas 2013, AbBAs \& Hussain 2015); Al-Rasheed, Aqar Quf (Al-OBAidi et al. 2017); (20) Huwaiza Marshes (AL-ZubAidi et al. 2017); (21) Samawa (Anonymous 2018).

New records. (22) Samarra, (23) Fallujah, (24) Yusifiya.

A broadly distributed species across most of Iraq (Fig. 23).

\section{Persian jird, Meriones persicus (Blanford, 1875)}

Published records. (1) Ser Amadia, (2) Kani Mase (Harrison 1956a); (3) Salahadin, (4) Shaqlawa (Hatt 1959); (5) Penjwin, (6) Kirkuk (Baltazard \& Seydian 1960); Penjwin, (7) Mullah Abd Allah (Petter et 
al. 1957, Petter 1961); (8) Shanidar Cave (Perkins 1964, Mohammad et al. 2017); (9) Palegawra Cave (Turnbull \& Reed 1974).

Museum records. (5)Penjwin, 1957(MNHN); (7)MullahAbdAllah, 1961 (MNHN); (10) Jarmo, 1955(FMNH). New records. Shaqlawa (4).

A species restricted to mountainous areas of northeastern Iraq (Fig. 24).

\section{Tristram's jird, Meriones tristrami (Thomas, 1892)}

Published records. (1) Dohuk (Ellerman 1948); (2) 10 km east of Kirkuk (Petter et al. 1957); (3) Kirkuk (Baltazard \& Seydian 1960); (4) Mullah Abd Allah (Petter 1961); (5) Bakrajo in Sulaymaniyah, (6) Sersink (Hatt 1959); (7) Mosul (NADACHOWSKI et al. 1990).

New records. (6) Sersink, (7) Mosul.

A rather rare species occurring only in the northeastern part of the country (Fig. 25).

\section{Libyan jird, Meriones libycus (Lichtenstein, 1823)}

Published records. (1) Ali Al-Gharbi (GePTnER 1940); (2) Al-Zubair, (3) Ameriya, (4) Jazira Desert, (5) Wadi Al-Tharthar (Harrison 1956b); (6) At Tuba (Hatt 1959); Ali Al-Gharbi (BaltazArd \& SEYdian 1960, Petter 1961); (7) Rutba (Nadachowski et al. 1990); (8) south of Basrah in the Demilitarized zone between Iraq and Kuwait (Alsdirawi \& FaraJ 2004); (9) Al-Rasheed (Salman 2009); Al-Rasheed, (10) Aqar Quf (Al-Obaidi et al. 2017); (11) Huwaiza Marsh (Al-Zubaidi et al. 2017).

New records. (12) Fallujah.
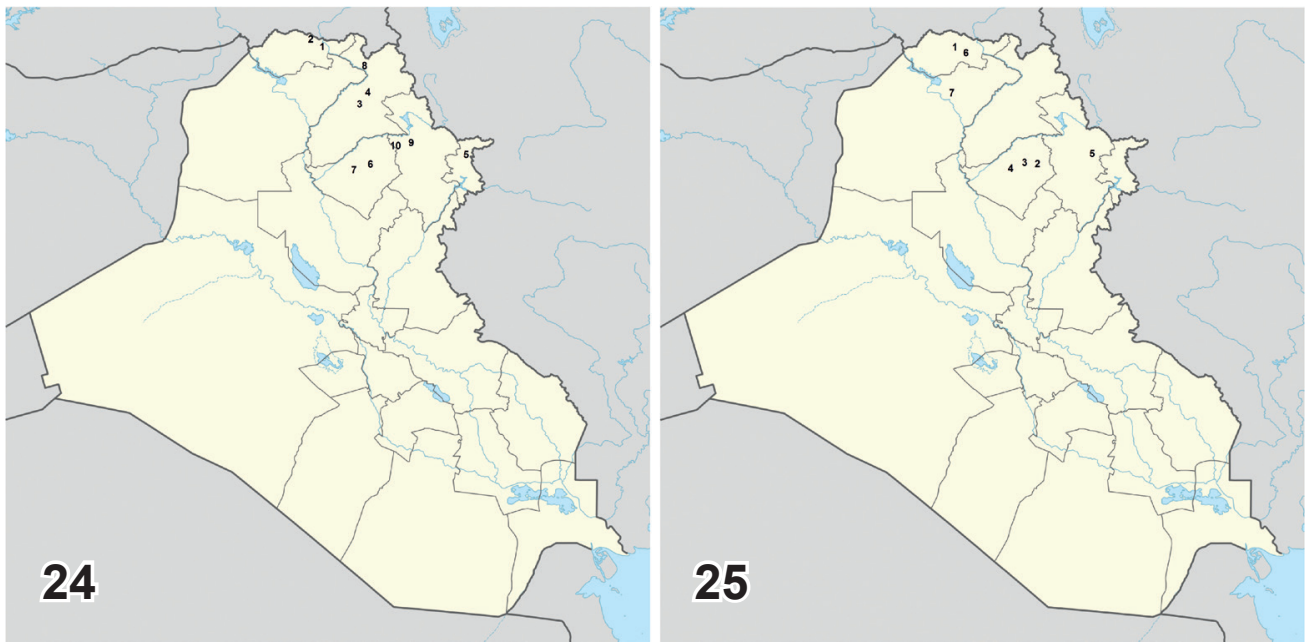

Figs. 24, 25. Distribution of particular rodent species in Iraq. The numbers in the maps correspond with the site numbers in the lists of records. 24 - Persian jird (Meriones persicus). 25 - Tristram's jird (Meriones tristrami).

Obr. 24, 25. Rozšiření jednotlivých druhů hlodavců v Iraku. Čísla v mapě odpovídají číslům lokalit v soupisech nálezů. 24 - pískomil perský (Meriones persicus). 25 - pískomil Tristramův (Meriones tristrami). 

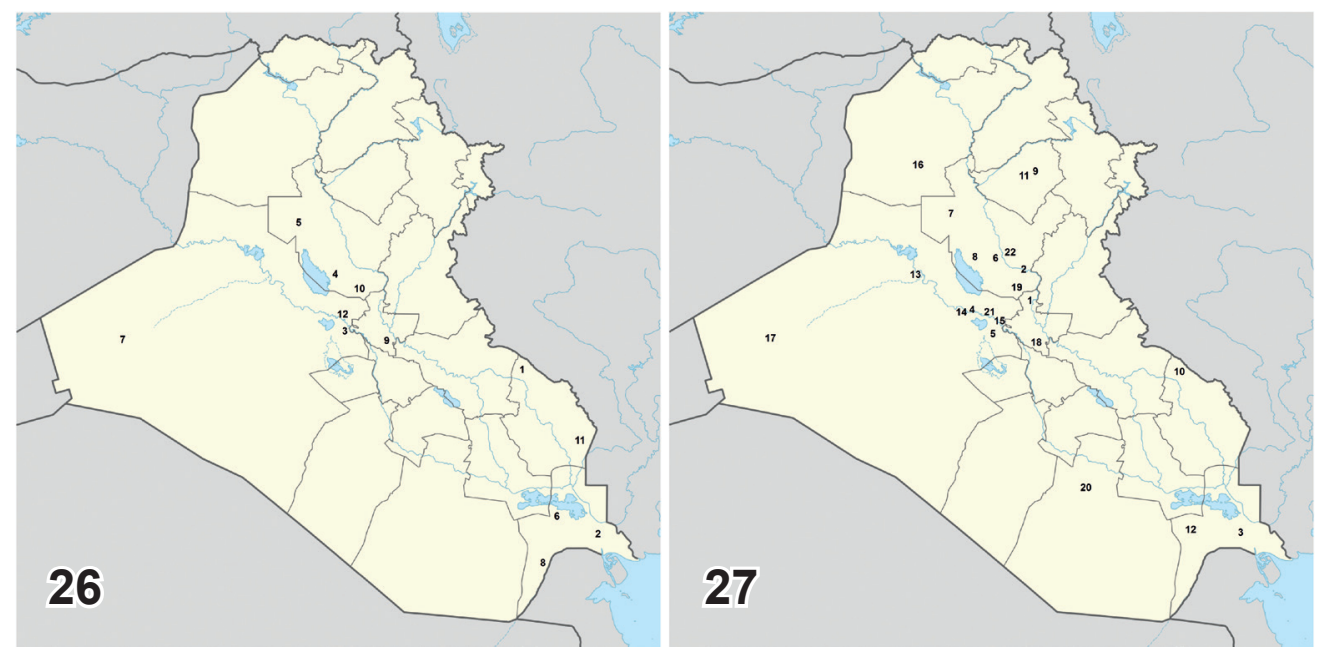

Figs. 26, 27. Distribution of particular rodent species in Iraq. The numbers in the maps correspond with the site numbers in the lists of records. 26 - Libyan jird (Meriones libycus). 27 - Sundevall's jird (Meriones crassus).

Obr. 26, 27. Rozšiřrení jednotlivých druhů hlodavců v Iraku. Č́śla v mapě odpovídají číslům lokalit v soupisech nálezů. 26 - pískomil rudoocasý (Meriones libycus). 27 - pískomil hedvábný (Meriones crassus).

A species broadly distributed across Iraq but rather rare (Fig. 26).

\section{Sundevall's jird, Meriones crassus (Sundevall, 1842)}

Published records. (1) Kadumiya, (2) Balad, (3) Al-Zubair (ChEesman 1920); (4) Ramadi (HubBard 1955, 1956); (5) Hawr Al-Hasa, (6) near Samarra, (7) Jazira Desert, (8) Wadi Al-Tharthar (HARrison 1956b); (9) Kirkuk (Baltazard \& Seydian 1960); Baghdad (HubBard 1960); (10) Ali Al-Gharbi, (11) Mullah Abd Allah (Petter et al. 1957, Petter 1961); Balad, (12) $150 \mathrm{~km}$ northwest of Basra, (13) Haditha, (14) $24 \mathrm{~km}$ west of Ramadi, (15) $32 \mathrm{~km}$ west of Baghdad (Hatt 1959); Balad (Harrison 1972, Harrison \& Bates 1991); (16) Hatrah, (17) Rutba (NADACHOWSKI et al. 1990); (18) Al-Rasheed (SALman 2009); Al-Rasheed, (19) Aqar Quf (Al-Obaidi et al. 2017); (20) Samawa (Anonymous 2018).

Museum records. (1) Kadumiya (BMNH); (3) Al-Zubair (BMNH); (10) Ali Al-Gharbi (MNHN); (11) Mullah Abd Allah (MNHN); (4) Ramadi (BRCB).

New records. (21) Fallujah, (22) Samarra.

Records of this species are scattered across most of the country (Fig. 27).

\section{Eurasian water vole, Arvicola amphibius (Linnaeus, 1758)}

Published records. (1) Penjwin (Baltazard \& Seydian 1960, Petter 1961, Harrison \& Bates 1991); (2) Palegawra Cave (Turnbull \& ReEd 1974); (3) Central and Southern Marshes (Al-Sheikhty et al. 2015). New records. (4) Sulaymaniyah. 
The range of this vole in Iraq has two disjunctive parts, in northern and southeastern Iraq (Fig. 28).

\section{Social vole, Microtus socialis (Palas, 1773)}

Published records. (1) Ser Amadiya (Harrison 1956b); (2) Sulaymaniyah, (3) Sersink (HatT 1959); (4) Penjwin (Baltazard \& Seydian 1960, Petter 1961); (5) Palegawra Cave (Turnbull \& Reed 1974); (6) Hawraman Mountain (LAHONY et al. 2013).

Museum records. (4) Penjwin (MNHN); (7) Chamchamal (MNHN).

A species rarely found in the northeastern parts of the country (Fig. 29).

Cricetid a e

\section{Grey dwarf hamster, Cricetulus migratorius (Pallas, 1773)}

Previous records. (1) Ser Amadia (Harrison 1956a); (2) Penjwin (Baltazard \& Seydian 1960); Penjwin, (3) Kirkuk (Petter 1961); (4) Palegawra Cave (Turnbull \& Reed 1974).

Museum records. (2) Penjwin (MNHN); (5) Jarmo, 1955 (FMNH).

A species restricted to mountainous areas of northern Iraq (Fig. 30).
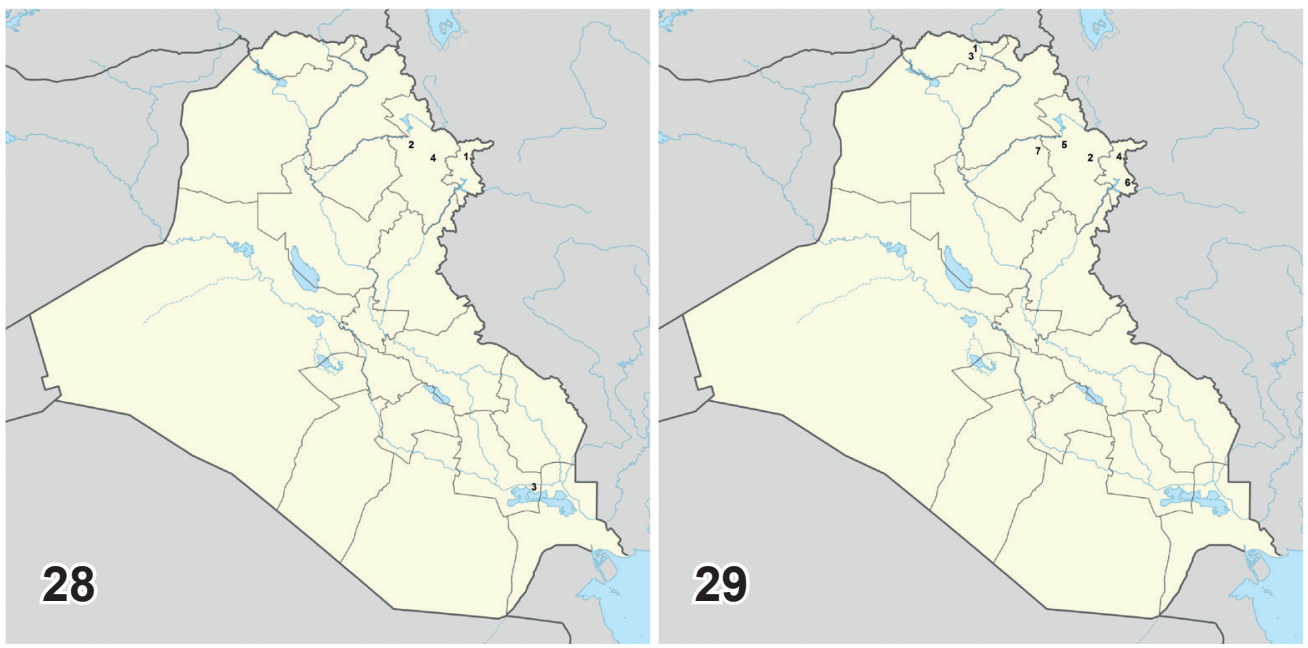

Figs. 28, 29. Distribution of particular rodent species in Iraq. The numbers in the maps correspond with the site numbers in the lists of records. 28 - Eurasian water vole (Arvicola amphibius). 29 - social vole (Microtus socialis).

Obr. 28, 29. Rozšíření jednotlivých druhů hlodavců v Iraku. Čísla v mapě odpovídají číslům lokalit v soupisech nálezů. 28 - hryzec vodní (Arvicola amphibius). 29 - hraboš pospolitý (Microtus socialis). 


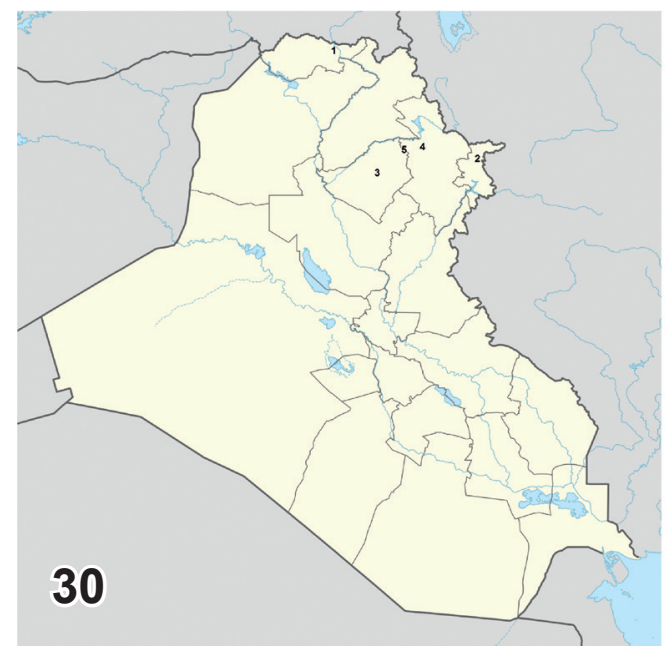

Fig. 30. Distribution of particular rodent species in Iraq. The numbers in the maps correspond with the site numbers in the lists of records. Grey dwarf hamster (Cricetulus migratorius).

Obr. 30. Rozšíření jednotlivých druhů hlodavců v Iraku. Čísla v mapě odpovídají číslům lokalit v soupisech nálezů. Křečík šedý (Cricetulus migratorius).

\section{DISCUSSION}

The current study provides updated information on the distribution of 29 species (17 genera from seven families) of rodents in Iraq. In comparison, the following numbers of rodent species were recorded in the neighboring countries: Iran 76 species (YUSEFI et al. 2019); Turkey 64 (Kryštufek \& Vohralík 2009); Syria 26 (Harrison \& Bates 1991); Jordan 28 (Amr et al. 2018); Saudi Arabia 18 (StUART \& StUART 2017), and Kuwait 12 (Cowan 2013).

However, in the current checklist of rodents, there are still some controversial species whose occurrence needs to be confirmed in Iraq. The presence of Ellobius lutescens in Iraq is still doubtful although BATE (1930) found fossilized remains in the caves of Hazar Mard. Then, HATT (1959) reported the same species to be found deep in the Shanidar Cave. According to HatT (1959), this species could still occur in the mountains of northern Iraq. BRAIDwOod \& HowE (1960) noted this species is most probably present in the mountains of Hazar Merd but no confirmed specimen has been reported. On the other hand, BALTAZARD \& SeYdian (1960) recorded this species from Penjwin, however, PetTer (1961) could not confirm this record since he did not find any specimen from the same locality. With the absence of a voucher specimen, this species cannot be included in this checklist. Similarly, PetTer (1961) recorded Dipodillus rupicola from Ali Al-Gharbi in southeastern Iraq and this specimen was included in the collection of the MNHN. However, no other specimen has ever been reported from Iraq. But the main problem with this species is that this rodent is found only in Mali (in Africa) and it is highly doubtful that it could be distributed in Iraq. In addition, it has never been found in any areas around Iraq. 
Table 1. Composition of the rodent fauna of Iraq

Tab. 1. Složení hlodavčí fauny Iraku

\begin{tabular}{|c|c|c|}
\hline family / čeled' & genus / rod & species / druh \\
\hline Sciuridae & Sciurus & Sciurus anomalus \\
\hline Hystricidae & Hystrix & Hystrix indica \\
\hline Dipodidae & $\begin{array}{l}\text { Allactaga } \\
\text { Jaculus }\end{array}$ & $\begin{array}{l}\text { Allactaga euphratica } \\
\text { Jaculus jaculus }\end{array}$ \\
\hline Gliridae & $\begin{array}{l}\text { Eliomys } \\
\text { Dryomys }\end{array}$ & $\begin{array}{l}\text { Eliomys melanurus } \\
\text { Drvomys nitedula }\end{array}$ \\
\hline Spalacidae & Nannospalax & Nannospalax ehrenbergi \\
\hline \multirow[t]{9}{*}{ Muridae } & Apodemus & $\begin{array}{l}\text { Apodemus mystacinus } \\
\text { Apodemus flavicollis } \\
\text { Apodemus sylvaticus } \\
\text { Apodemus witherbyi }\end{array}$ \\
\hline & Rattus & $\begin{array}{l}\text { Rattus rattus } \\
\text { Rattus norvegicus }\end{array}$ \\
\hline & Mus & Mus musculus \\
\hline & Nesokia & $\begin{array}{l}\text { Nesokia indica } \\
\text { Nesokia bunnii }\end{array}$ \\
\hline & Gerbillus & $\begin{array}{l}\text { Gerbillus henleyi } \\
\text { Gerbillus nanus } \\
\text { Gerbillus dasyurus } \\
\text { Gerbillus mesopotamiae } \\
\text { Gerbillus cheesmani }\end{array}$ \\
\hline & Tatera & Tatera indica \\
\hline & Meriones & $\begin{array}{l}\text { Meriones persicus } \\
\text { Meriones tristrami } \\
\text { Meriones libycus } \\
\text { Meriones crassus }\end{array}$ \\
\hline & Arvicola & Arvicola amphibius \\
\hline & Microtus & Microtus socialis \\
\hline Cricetidae & Cricetulus & Cricetulus migratorius \\
\hline
\end{tabular}

Microtus socialis and M. irani were both recorded from Iraq. HubBard $(1956,1960)$ collected one specimen of M. irani from Sersink, northern Iraq. PetTER et al. (1957) collected both species from Penjwin. HubBard (1955) and HatT (1959) also reported these two rodents from Iraq. However, Harrison (1972) and HARrison \& Bates (1991) considered HatT's records of M. irani to represent in fact records of M. socialis. ELLERMAN (1948) obtained some specimens from Baghdad but he doubted whether these specimens actually came from that area. As for its zoogeographic distribution in Iraq, $M$. irani could be very likely present in the northeastern areas of Iraq. But no voucher specimens have been captured since the records provided by Ellerman (1948), HubBard $(1955,1956,1960)$ and Hatt (1959). Microtus irani has been recorded from Turkey, Syria, and Lebanon (Kock \& NAder 1983, KRYŠTufeK \& Vohralík 2009, KRYŠTUFEK et al. 2013).

Nannospalax ehrenbergi and Spalax leucodon were both previously reported from Iraq. However, in the current review, only Nannospalax ehrenbergi was included and no other spe- 
cies of Spalacidae was found despite extensive field research in the localities where Spalax leucodon was previously reported. HuBBARD (1955) and HaTT (1959) reported the existence of both species from northern areas in Iraq. LAHONY et al. (2013) mentioned Spalax leucodon from the Hawraman Mountain, but this information relied only on previous records and no voucher specimens were collected during their study. HARrison (1956a) and REED (1958) observed Spalax leucodon in northern Iraq. But the latter authors questioned if both $S$. leucodon and $N$. ehrenbergi are really found in Iraq noting that $N$. ehrenbergi and $S$. leucodon could possibly intergrade and might not be, in the end, separate species.

KHAJURIA (1981) found two rodents in southern Iraq and assigned them to a new genus Erythronesokia. Later, based on body size and the main differences in coloration and the comparatively smaller mastoid and zygomatic widths, Al-RobaAe \& Felten (1990) indicated that this is just a subgenus of Nesokia (Nesokia bunnii) and not a separate genus. However, HARRISON \& BATES (1991) proposed that these specimens could temporarily be considered as Nesokia indica.

FADHIL et al. (2009) reported Apodemus arianus from an area nearby Al Asad Oasis in the Anbar Province; this name is a synonym for Apodemus flavicollis. However, this rodent is very unlikely to be distributed in such an arid area as Apodemus flavicolis is known to be restricted to the forests of northern Iraq.

AbBas (2013) and ABBAS \& Hussain (2015) noted that they were unable to collect a single specimen of Nesokia bunnii during a 12-month period. They suggested that this species might have become extremely rare to collect or regionally extinct.

The historical existence of Castor fiber in Iraq remains uncertain. PERKINS (1964) reported beaver mandible from the cave of Shanidar on the Greater Zab river in Iraq. TURNBULL \& REED (1974) also reported beaver bones from the Palegawra Cave. However, in the 19th century records of beaver occurrence along the Euphrates and Tigris rivers were possible. While passing through an area near Deir Al-Zawr in Syria, AinsworTh (1888) reported that the Arabs brought him beaver skins for sale. Similarly, LAYARD (1853) suggested beaver existence on the Khabour river when he reported that a local Arab tribe killed four and brought him another three youngsters. According to LAYARD (1853), beavers were once very common on the Khabour, but they have been hunted almost to extermination by the Arabs. However, HatT (1959) and HARRISON (1972) dismissed these reports suggesting that otters were misidentified as beavers. LEGGE \& RowLEY-CONwY (1986) noted that previous literature sources suggested that beavers lived in the Tigris-Euphrates basin into the historic period and that the beaver was a part of the fauna in mountain regions of Iraq from the Late Pleistocene and into historic times. LANDSBERGER (1934) included the beaver as a member of the ancient Mesopotamian fauna.

As for the medical importance of rodents, many rodent species that are found in Iraq are classified as reservoirs harboring diseases caused by different organisms such as viruses, bacteria, fungi, protozoa and helminths. Several studies showed that Tatera indica, Meriones crassus, M. libycus, and Nesokia indica in Iraq are infested with different parasites, especially the flea Xenopsylla cheopis (Rotschild, 1903) which is known for its role in transmitting plague and murine typhus among humans (Hasson \& Al-Zubaidi 2011, Al-OBaidi et al. 2017). Other studies found that Rattus rattus, $R$. norvegicus, and Mus musculus were infected with different kinds of pathogens (JaWdat \& Al-JAFARY 1980, JAWdat \& Mahmoud 1980, Molan \& Hussein 1988, Mohammad 1999, Al-Zihiry 2006, Karim \& Al-Salihi 2014, Amin 2019).

Rodents in Iraq face many threats but hunting remains the main danger. Squirrels are hunted, captured and sold as pets. Porcupines are hunted and killed in many areas in Iraq. Locals in some western and central areas of Iraq eat porcupines claiming that its meat is a medicine 
for stomach pain and some other diseases. In addition, quills are used for decoration and as a drawing tool among painters. In the same way, jerboas are hunted and killed as food and this practice is common only among Bedouins in western Iraq (AL-ANi 1980).

The Iraqi Public Health Law No. 7 (1981) provided all technical details on the rodent control required in residential and commercial buildings. However, very little effort has been made to tackle this problem and rodent control still represents a challenging issue in Iraq. With the current ineffective control methods, Iraq needs better interventions to be able to solve the ongoing problem of the uncontrolled distribution of the commensal rodents in Iraq (KADHIM 1988, 1991, KADHIM \& MAHDi 2017). Different mechanical, biological and chemical control methods were used in Iraq but no single method proved to be very effective in eradication. Commensal rodents are known to thrive in accumulations of trash in urban or rural areas. One of the possible reasons for the current ongoing uncontrolled distribution of rodents in Iraq could be the absence of an effective municipal waste management system in addition to the lack of an inclusive centralized government plan to deal with the rodent control issue.

\section{SOUHRN}

Př́spěvek stručně shrnuje aktualisované informace o složení a rozšíření fauny hlodavců Iraku. Presentované údaje byly shormážděny výzkumem v terenu v létech 2018-2019 a především shrnutím dřive publikovaných nálezů, jakož i dílčí revisí vybraných musejních sbírek. Podle dostupných údajů sestává fauna hlodavců Iraku z 29 druhů rozlišovaných současnou taxonomií a řazených do 17 rodů a sedmi čeledí (tab. 1).

\section{REFERENCES}

AbBas A. F., 2013: The Relative Abundance and Biological Indicators of Mammals' Community in East Hammar. Unpubl. MSc Thesis. University of Basra, Basra, 80 pp.

AbBas A. F. \& Hussain N. A., 2015: Occurrence of wild mammals at the restored East Hammar Marsh Basrah -Iraq. Marsh Bulletin, 10: 25-35.

Abdul-Rassoul M. S. \& Mohammad M. K., 1988: Ticks (Ixodoidea, Acarina) of desert in Iraq. Bulletin of the Iraq Natural History Museum, 8: 11-24.

Ainsworth W. F., 1888: A Personal Narrative of the Euphrates Expedition. Kegan Paul \& Trench, London, $447 \mathrm{pp}$.

AL-ANI M. R., 1980: Diet and dietary habits of nomads in Iraq. Ecology of Food and Nutrition, 9: 55-57.

AL-JeBori A. K., 2016: Histomorphplogical study of kidney in Iraqi jerboa (Jaculus jaculus). Euphrates Journal of Agriculture Science, 8: 69-82.

Al-Obaidi M. J., Hanoon A. Y., NaYef H. J. \& Abdul Wahab I., 2017: Trap Night Index (TNI), prevalence and parasitological importance of rodents in two rural areas of Baghdad Province, Iraq. Current Research in Microbiology and Biotechnology, 5: 1038-1042.

Al-RobaAe K., 1976: On a collection of mammals from Mosul, North Iraq. Bulletin of Basrah Natural History Museum, 3: 67-76

Al-RobaAe K., 1977: Distribution of Nesokia indica (Gray \& Hardwicke, 1830) in Basrah Liwa, south Iraq. With some biological notes. Säugetierkundliche Mitteilungen, 25: 194-197.

Al-RobaAe K. \& Felten H., 1990: Was ist Erythronesokia Khajuria, 1981 (Mammalia: Rodentia: Muridae)? Zeitschrift für Säugetierkunde, 55: 253-259.

Al-Sheikhly O. F., Haba M. K., Barbanera F., Csorba G. \& Harrison D. L., 2015: Checklist of the mammals of Iraq (Chordata: Mammalia). Bonn Zoological Bulletin, 64: 33-58.

Al-ShEnAwi F. A., JAWDAT S. Z. \& Al-JAFARY A. R., 1982: Investigation on the natural reservoir hosts of Leishmania spp. in some endemic areas of Iraq. Journal of Biological Sciences Baghdad, 13: 27-34. 
Al-Zubaidi A. A., Jane S. K. \& Hadi A. M., 2014: Geological diversity and its importance on biodiversity SW Safeen Mountain - Erbil, Kurdistan, North Iraq. Advances in Bioresearch, 5: 53-60.

Al-Zubaidi A. A., Mohammad M. K. \& Rasheed M. J., 2017: The importance of geodiversity on the animal diversity in Huwaiza marsh and the adjacent areas, southeastern Iraq. Bulletin of the Iraq Natural History Museum, 14: 235-249

AL-ZIHIRY K. J. K., 2006: Some intestinal helminths of Norway rat Rattus norvegicus Berkenhout 1769 in Basrah Iraq. Journal of University of Thi-Qar, 2(1): 1-12.

AlsDiraWi F. \& FARAJ M., 2004: Establishing a transboundary peace park in the demilitarized zone (DMz) on the Kuwait/Iraq borders. Protected Areas Programme, Parks Magazine, 14: 48-55.

Amin O. M., 2019: Intestinal and ectoparasites of black rats (Rattus rattus) in Garmian, Kurdistan region of Iraq. Journal of the University of Garmian, 6: 623-629.

Amr Z. S., BaKer M. A. A., QumsiYeh M. \& Eid E., 2018: Systematics, distribution and ecological analysis of rodents in Jordan. Zootaxa, 4397: 1-94.

Anonymous, 2018: Samawa Combined Cycle Gas Turbine Power Plant Project: Environmental and Social Impact Assessment (ESIA) Report. Project No: 17/003. Iraqi Ministry of Electricity, Baghdad, 276 pp.

Baltazard M. \& Seydian B., 1960: Enquete sur les conditions de la Peste au Moyen Orient. Bulletin of the World Health Orgnization, 23: 157-167.

Bate D. M., 1930: Animal remains from Dark Cave, Hazar Merd. Bulletin of the American School Prehistoric Research, 6: 38-41.

Braidwood R. J. \& Howe B., 1960: Prehistoric Investigations in Iraqi Kurdistan. Studies in Ancient Oriental Civilization. The University of Chicago Press, Chicago, 184 pp.

Bryja J., Meheretu Y., Šumbera R. \& Lavrenchenko L. A., 2019: Annotated checklist, taxonomy and distribution of rodents in Ethiopia. Folia Zoologica, 68: 117-213.

Cheesman R. E., 1920: Report on the mammals of Mesopotamia collected by members of the Mesopotamian Expeditionary Force, 1915-1919. Journal of the Bombay Natural History Society, 27: 323-346.

Coşrun Y., El Namee A., Kaya A. \& Rahemo Z. I. F., 2012: Karyotype of Nannospalax ehrenbergi (Nehring 1898) (Rodentia: Spalacidae) in the Mosul Province, Iraq. Hystrix, n. s., 23: 72-75.

CoşKun Y., Asan Baydemir N., KaYa A. \& Karöz A., 2014: Nucleolar organizer region distribution in Nannospalax ehrenbergi (Nehring, 1898) (Rodentia: Spalacidae) from Iraq. Turkish Journal of Zoology, 38: $250-253$.

Coșkun Y., Hamad Z. A. \& KaYa A., 2016: Morphological properties of Nannospalax (Rodentia: Spalacidae) distributed in North-Iraq. Hacettepe Journal of Biology \& Chemistry, 44: 173-179.

Cowan P. J., 2013: An annotated checklist of the mammals of Kuwait. Sultan Qaboos University Journal for Science, 18: 19-24.

Dahmana H., Granjon L., Diagne C., Davoust B., Fenollar F. \& Mediannikov O., 2020: Rodents as hosts of pathogens and related zoonotic disease risk. Pathogens, 9(3): 202.

Ellerman J. R., 1948: Key to the rodents of south-west Asia in the British Museum collection. Proceedings of the Zoological Society of London, 118: 765-816.

Evans M., 1994: Important Bird Areas in the Middle East. Bird Life International, Norwich, 410 pp.

Fadhil O., Salim M. A., Abd I. M. \& Bachmann A., 2009: Key Biodiversity Survey of Central and Western Iraq. Nature Iraq, Sulaymaniyah, $101 \mathrm{pp}$.

GePtneR V. G., 1940: Fauna pesčanok (Mammalia Glires) Irana i zoogeografičeskie osobennosti Maloaziatsko-Irano-Afganskih stran [The fauna of gerbills (Mammalia Glires) of Iran and zoogeographical particularities of the regions of the Asia Minor, Iran, and Afghanistan]. Novye Memuary Moskovskogo Obŝestva Ispytatelej Prirody, 20: 5-71 (in Rusian).

HaвA M. K., 2009: Mesopotamian Marshland Mammals. Marsh Bulletin, 4(2): 179-189.

HABA M. K., 2013: Documentation some mammals in Iraqi Kurdistan region. Science Journal of University of Zakho, 1: 549-555.

Hatem A. N., Abou Turab M. K. \& Abdul-Zahra H. K., 2018: Diversity and seasonal occurrence of ticks from some wild mammals in south of Iraq. Journal of Entomology and Zoology Studies, 6: 2788-2791. 
Hamad Z. A., Kaya A. \& Coșkun Y., 2019: Geographical distribution and karyotype of Nannospalax ehrenbergi (Nehring 1898) (Rodentia, Spalacidae) in Iraq. Caryologia, 72: 79-83.

HARrison D. L., 1956a: Mammals from Kurdistan, Iraq, with description of a new bat. Journal of Mammalogy, 37: 257-263.

HARRISON D. L., 1956b: Gerbils from Iraq, with description of a new gerbil. Journal of Mammalogy, 37: 417-422.

HARRISON D. L., 1958: Observations on infant jerboas with special reference to the development of the tympanic bulla. Journal of Mammalogy, 39: 395-398.

Harrison D. L., 1972: The Mammals of Arabia. Volume 3. Lagomorpha, Rodentia. Ernest Benn, Ltd., London, 385-670 pp.

Harrison D. L. \& Bates P. J. J., 1991: The Mammals of Arabia. Harrison Zoological Museum, Sevenoaks, $354 \mathrm{pp}$.

Hasson R. H. \& Al-Zubaidi H. H., 2011: Ectoparasites of rodents from some districts in Baghdad. Wassit Journal for Science \& Medicine, 4(2): 19-28.

Hatt R. T., 1959: The mammals of Iraq. Miscellaneous Publications, Museum of Zoology, University of Michigan, 106: 1-113.

HuBBARD C. A., 1955: Some ticks from Iraq. Entomological News, 66: 189-191.

Hubbard C. A., 1956: Six new fleas from Iraq. Iraq Natural History Museum Publications, 11: 1-12.

HubBard C. A., 1958: Fleas and plague in Iran and the Arab World. Part I. Iraq Natural History Museum Publications, 15: 1-142.

Hubbard C. A., 1960: Fleas and plague in Iran and the Arab World. Part II. Iraq Natural History Museum Publications, 19: 1-143.

JAWDAT S. Z., 1977: A new record of forest dormouse, Dryomys nitedula Pallas (Rodentia: Muscardinidae) in Iraq. Bulletin of the Natural History Research Centre University of Baghdad, 9: 115.

JAWDAT S. Z. \& Al-JaFARY A. R., 1980: A survey and studies on some protozoa found in the gut of some rodents in Iraq. Bulletin of the Biological Research Centre, Baghdad, 12: 71-86.

JaWDAT S. Z. \& MAHMOUD S. N., 1980: The incidence of cestoidean and acanthocephalan parasites of some rodents in Iraq. Bulletin of the Natural History Research Centre, 7(4): 55-71.

JoRDAN K., 1938: On some Siphonaptera from tropical Africa and Iraq. Novitates Zoologicae, 41: $112-118$.

Kadhim A. H., 1988: [Rodents Control]. Freedom Printing Press, Baghdad, 182 pp (in Arabic).

Kadhim A. H., 1991: Rodents, Ecology, Biology \& Control Methods. General Public Affairs Press, Baghdad, 328 pp (in Arabic).

KadHim A. H. H., 1997: Distribution and reproduction of the Indian crested porcupine Hystrix indica (Hystricidae: Rodentia) in Iraq. Zoology in the Middle East, 15: 9-12.

KadHim A. H. H., 1998: Winter breeding of the Indian gerbil, Tatera indica (Rodentia: Gerbillinae), with reference to its first recorded outbreak in Iraq. Zoology in the Middle East, 16: 9-12.

KADHIM A. B., 2017: Macroanatomical and histological study of kidney in porcupine (Hystrix cristata). Al-Qadisiyah Journal of Veterinary Medicine Sciences, 16: 88-92.

KadHIM A. B., 2018: Histomorphological investigation of tongue of porcupine Hystrix cristata. Iraqi Journal of Veterinary Medicine, 42: 12-17.

KadHim A. H. \& MAHDI H. Q., 2017: Recent status of prevalence of rodents infestation in Baghdad city. Ibn Al-Haitham Journal for Pure and Applied Science, 21(4): 12-18.

Kadhim A. H., Mustafa A. M. \& Jabir H. A., 1979: Biological notes on jerboas Allactaga euphratica and Jaculus jaculus from Iraq. Acta Theriologica, 24: 93-98.

Kadhim A. H. H., Elias A, Al-NaKash M. M. \& Wahid I. N., 1986: Preliminary observations on rodents exist in alfalfa farms. Journal of Biological Sciences Research, 17: 59-67.

KhaJURIa H., 1981: A new bandicoot rat, Erythronesokia bunnii gen. et sp. nov. (Rodentia: Muridae), from Iraq. Bulletin of the Natural History Research Centre, 7: 157-164.

Karim A. J. \& Al-SAlihI K. A., 2014: Diagnostic study on accidental Hymenolepis diminuta infection in laboratory rats in Iraq. Mirror of Research in Veterinary Sciences and Animals, 3(3): 33-40. 
Khedher A. A., 2014: Configuration of burrow sites of yellow-necked field mouse (Apodemus flavicollis argyropuli) in field crop biotopes in Iraqi Kurdistan. Hungarian Small Game Bulletin, 12: 373-382.

Khedher A. A. \& Khalaf A. A., 2019: Effect of some edaphic factors and the distribution of yellownecked field mouse (Apodemus flavicollis argyropuli) in field crop biotopes. Journal of University of Duhok, 22: 9-24.

Kock D. \& Nader I. A., 1983: Pygmy shrew and rodents from the Near East (Mammalia: Soricidae, Rodentia). Senckenbergiana Biologica, 64: 12-23.

Kryštufek B. \& Vohralík V., 2009: Mammals of Turkey and Cyprus. Introduction, Checklist, Rodentia II. Knjižnica Annales Majora, Koper, 372 pp.

KryštufeK B., Abi-SaId M. \& Hladnik M., 2013: The Iranian vole Microtus irani occurs in Lebanon (Mammalia: Rodentia). Zoology in the Middle East, 59: 101-106.

KryŠtufek B., Al-Sheikhly O. F. \& Hutterer R., 2017: A redescription of the long-tailed nesokia, Nesokia bunnii, and designation of a neotype (Rodentia: Muridae). Zootaxa, 4216: 167-187.

Lahony S. R. A., Mohammad M. K., Ali H. H., Al-Moussawi A. A. \& Abd Al-Rasul M. S., 2013: Fauna and flora of Hawraman Mountain (Part one). Hawraman lowest zone, Kurdistan Province North East of Iraq. Bulletin of Iraq Natural History Museum, 12(4): 7-34.

LANDSBERger B., 1934: Die Fauna des alten Mesopotamien nach der 14. Tafel der Serie Har-ra = hubullu. Abhandlungen der Sächsischen Akademie der Wissenschaften zu Leipzig, Philologisch-Historische Klasse, 42: i-xiv+1-144.

Layard A. H., 1853: Discoveries in the Ruins of Nineveh and Babylon. Murray, London, $338 \mathrm{pp}$.

Legge A. J. \& Rowley-Conwy P. A., 1986: The beaver (Castor fiber L.) in the Tigris-Euphrates basin. Journal of Archaeological Science, 13: 469-476.

von Lehmann E., 1966: Taxonomische Bemerkungen zur Säugerausbeute der Kummerloeweschen Orientreisen 1953-1965. Bonner Zoologische Beiträge, 12: 251-317.

LEWIS R. E., 1974: Notes on the geographical distribution and host preferences in the order Siphonaptera. Part 4. Coptopsyllidae, Pygiopsyllidae, Stephanocircidae and Xiphiopsyllidae. Journal of Medical Entomology, 11: 403-413.

Mahdi N. \& George P. V., 1969: Systematic list of Iraqi vertebrates - mammals. Bulletin of the Iraq Natural History Museum, 26: 34-63.

MAJEED S. A., 2016: Prevalence of intestinal parasites in Rattus rattus in some districts in Baghdad/Iraq. Al-Anbar Journal of Veterinary Sciences, 9: 43-48.

MiRzA M. Y. \& Al-RawAS A. Y., 1975: Eimeria taterae sp. n. and other intestinal parasites from the antelope rat, Tatera indica in Baghdad District. Journal of Protozoology, 22: 23-24.

Mohammad M. K., 1999: Species the soft tick genus Argas (Acarina, Ixodoidea) in Iraq. Bulletin of the Iraq Natural History Museum, 9: 131-135.

Mohammad M. K., 2008: The parasitic fauna and the food habits of the wild jungle cat Felis chaus furax de Winton, 1898 in Iraq. Bulletin of the Iraq Natural History Museum, 10: 65-78.

Монаммад M. K., 2014: The current status of the vertebrate diversity in Al-Dalmaj Marsh, Al-Diwaniya Province. Bulletin of the Iraq Natural History Museum, 13: 5-14.

Moнammad M. K. \& Ali H. H., 2013: [Studying biodiversity in Razzaza Lake and its neighboring areas]. Al-Ustath, 2: 23-34 (in Arabic).

Mohammad M. K. \& Al-Zubaidi A. A., 2017: Geodiversity and its importance on vertebrate diversity near Razzaza lake, middle of Iraq. Iraqi Geological Journal, 50: 104-123.

Mohammad M. K., Ali H. H., Ali B. A. \& Hadi A. M., 2013: The biodiversity of Bahr Al-Najaf depression, Al-Najaf Al-Ashraf Province. Bulletin of the Iraq Natural History Museum, 12: 21-30.

Mohammad M. K., Afrasiab S. R., Al-Zubaidi A. A. \& Abdul-Rassoul M. S., 2017: Survey for cave animals of Iraqi Kurdistan. Journal of Biodiversity and Environmental Sciences, 10: 217-232.

Molan A. L. \& Hussein M. M., 1988: A general survey of blood and tissue parasites of some rodents in Arbil province, Iraq. Acta Pathologica, Microbiologica et Immunologica Scandinavica, Supplementum, 3: $47-49$. 
Nadachowski A., Rzebik-Kowalska B. \& Kadhim A. H., 1978: The first record of Eliomys melanurus Wagner, 1840 (Gliridae, Mammalia), from Iraq. Säugetierkundliche Mitteilungen, 26: 206-207.

Nadachowski A., Śmietowski J., RzebiK-Kowalska B. \& Daoud A., 1990: Mammals from the Near East in Polish collections. Acta Zoologica Cracoviensia, 33: 91-120.

NADER I. A., 1968: Animal remains in pellets of the barn owl, Tyto alba from the vicinity of An-Najaf, Iraq. Bulletin of the Iraq Natural History Museum, 4: 1-7.

NADER I. A., 1969: Records of the shrew, Crocidura russula, from Iraq. Journal of Mammalogy, 50: 614-615.

Perkins D., 1964: Prehistoric fauna from Shanidar, Iraq. Science, 144(3626): 1565-1566.

Petter F., 1961: Repartition geographique et ecologie des rongeurs desertiques (du Sahara ocidentale a l'Iran oriental). Mammalia, 25: 1-222.

Petter F., Seydian B. \& Mostachfi P., 1957: Données nouvelles sur la repartition des Gerbillidés et de quelques autres rongeurs en Iran et en Irak. Mammalia, 21: 111-120.

Pietschmann V., 1912: Die österreichische Expedition nach Mesopotamien im Jahre 1910. Schriften des Vereines zur Verbreitung Naturwissenschaftlicher Kenntnisse in Wien, 52(12): 331-355.

Raza H. A., Ahmad S. A., Hassan N. A., Ararat K., Qadir M. \& Ali L., 2012: First photographic record of the Persian leopard in Kurdistan, northern Iraq. Cat News, 56: 34-35.

ReED C. A., 1958: Observations on the burrowing rodent Spalax in Iraq. Journal of Mammalogy, 39: 386-389.

SaLman S. A., 2009: Ecological aspects of dwelling position for a previous case of Kala-azar in south of Baghdad, Iraq. Ibn Al-Haitham Journal for Pure \& Applied Science, 22: 52-57.

SAnBorn C. C., 1940: Mammals from Iraq. In: Field H. (ed.): Anthropology of Iraq. Anthropological Series, Field Museum of Natural History, 30: 156-162.

Shahatha S. S. \& Saleh T. A., 2018: An epidemiological, diagnostic, and therapeutic study of the Leishmania tropica parasite in Iraq's Anbar Province. Baghdad Science Journal, 15: 392-400.

Shamsuddin M. \& Mohammad M. K., 1988: Incidence, distribution, and host relationships of some ticks (Ixodoidea) in Iraq. Journal of the University of Kuwait (Science), 15: 321-330.

Shubber H. W. K., Al-Hassani N. A. \& Mohammad M. K., 2014: Ixodid ticks diversity in the middle and south of Iraq. International Journal of Records Scientific Research, 5: 1518-1523.

Stuart C. \& Stuart T., 2017: Mammals of North Africa and the Middle East. Bloomsbury Publishing, Lodon, $128 \mathrm{pp}$.

Turnbull P. F. \& Reed C. A., 1974: The fauna from the terminal Pleistocene of Palegawra Cave, a Zarzian occupation site in northeastern Iraq. Fieldiana: Anthropology, 63: 81-146.

Wilson D. E., Lacher T. E. \& Mittermeier R. A. (eds.), 2017: Handbook of the Mammals of the World. Rodents II. Lynx Edicions, Barcelona, 1008 pp.

Yusefi G. H., Faizolahi K., Darvish J., Safi K. \& Brito J. C., 2019: The species diversity, distribution, and conservation status of the terrestrial mammals of Iran. Journal of Mammalogy, 100: 55-71. 